\title{
Collagen-Based Tissue Engineering Strategies for Vascular Medicine
}

\author{
Francesco Copes $^{1,2}$, Nele Pien ${ }^{1,3}$, Sandra Van Vlierberghe ${ }^{3}$, Francesca Boccafoschi ${ }^{1,2}$ and \\ Diego Mantovani ${ }^{1 *}$
}

\begin{abstract}
1 Laboratory for Biomaterials and Bioengineering, Canada Research Chair Tier I for the Innovation in Surgery, Department of Min-Met-Materials Engineering \& Regenerative Medicine, CHU de Quebec Research Center, Laval University, Quebec City, QC, Canada, ${ }^{2}$ Laboratory of Human Anatomy, Department of Health Sciences, University of Piemonte Orientale, Novara, Italy, ${ }^{3}$ Polymer Chemistry \& Biomaterials Group, Department of Organic and Macromolecular Chemistry, Centre of Macromolecular Chemistry, Ghent University, Ghent, Belgium
\end{abstract}

\section{OPEN ACCESS}

Edited by:

Hasan Uludag,

University of Alberta, Canada

Reviewed by:

John Law Brash,

McMaster University, Canada

Dimitrios I. Zeugolis,

National University of Ireland Galway,

Ireland

*Correspondence:

Diego Mantovani

diego.mantovani@gmn.ulaval.ca

Specialty section:

This article was submitted to

Biomaterials,

a section of the journal

Frontiers in Bioengineering and

Biotechnology

Received: 13 February 2019

Accepted: 24 June 2019

Published: 12 July 2019

Citation:

Copes F, Pien N, Van Vlierberghe S,

Boccafoschi F and Mantovani $D$

(2019) Collagen-Based Tissue

Engineering Strategies for Vascular

Medicine.

Front. Bioeng. Biotechnol. 7:166.

doi: 10.3389/fbioe.2019.00166
Cardiovascular diseases (CVDs) account for the 31\% of total death per year, making them the first cause of death in the world. Atherosclerosis is at the root of the most life-threatening CVDs. Vascular bypass/replacement surgery is the primary therapy for patients with atherosclerosis. The use of polymeric grafts for this application is still burdened by high-rate failure, mostly caused by thrombosis and neointima hyperplasia at the implantation site. As a solution for these problems, the fast re-establishment of a functional endothelial cell (EC) layer has been proposed, representing a strategy of crucial importance to reduce these adverse outcomes. Implant modifications using molecules and growth factors with the aim of speeding up the re-endothelialization process has been proposed over the last years. Collagen, by virtue of several favorable properties, has been widely studied for its application in vascular graft enrichment, mainly as a coating for vascular graft luminal surface and as a drug delivery system for the release of pro-endothelialization factors. Collagen coatings provide receptor-ligand binding sites for ECs on the graft surface and, at the same time, act as biological sealants, effectively reducing graft porosity. The development of collagen-based drug delivery systems, in which small-molecule and protein-based drugs are immobilized within a collagen scaffold in order to control their release for biomedical applications, has been widely explored. These systems help in protecting the biological activity of the loaded molecules while slowing their diffusion from collagen scaffolds, providing optimal effects on the targeted vascular cells. Moreover, collagen-based vascular tissue engineering substitutes, despite not showing yet optimal mechanical properties for their use in the therapy, have shown a high potential as physiologically relevant models for the study of cardiovascular therapeutic drugs and diseases. In this review, the current state of the art about the use of collagen-based strategies, mainly as a coating material for the functionalization of vascular graft luminal surface, as a drug delivery system for the release of pro-endothelialization factors, and as physiologically relevant in vitro vascular models, and the future trend in this field of research will be presented and discussed.

\footnotetext{
Keywords: collagen, tissue engineering, cardiovascular, coating, drug delivery system, vascular model
} 


\section{INTRODUCTION AND SHORT HISTORICAL PERSPECTIVE}

Cardiovascular diseases (CVDs) account for 17.9 million deaths each year, making them the leading cause of death in the world $\left(\mathrm{WHO}^{1}\right)$. Heart attacks and strokes account for $85 \%$ of these deaths. Most often, atherosclerosis is at the basis of these two pathologies. Atherosclerosis is a pathological progressive condition in which plaques, mainly due to the accumulation of lipids, cholesterol, foamy cells, and cellular debris, progressively grow inside the lumens, thus leading to the partial or complete obstruction of blood flow, and leading to severe medical conditions and, ultimately, to death. The increase of risk factors associated with the pathology (obesity, diabetes, hypertension, and smoking), coupled with the increase in average life expectancy, has led to the urgent search for durable and effective solutions. Vascular bypass/substitution surgery represents the most common, ultimate clinical treatment of occlusive CVDs. Autologous blood vessels, such as saphenous veins or radial arteries, that present the best structural, mechanical, and biological properties are the gold standard for this kind of application. However, the use of these substitutes is not always possible, due to the multiple surgical procedures required, or the poor general health conditions of patients. Some of the limiting factors for the use of autografts include the typical old age of the patients needing treatments, vascular diseases preventing the use of autologous vessels, and/or previous harvesting for other surgical treatments. In this light, the need for other sources of vascular substitutes is critically urgent. Synthetic prostheses development started in the 1950s and opened a therapeutic alternative for the replacement of injured arterial segments. The first synthetic vascular bypass has been performed in 1952 with the implantation of a porous textile prosthesis made of polyethylene terephthalate (PET), also known as Dacron ${ }^{\circledR}$ (Voorhees et al., 1952; Kannan et al., 2005). Prostheses made of Dacron ${ }^{\circledR}$ are usually applied for the replacement of vessels of large caliber ( $>10 \mathrm{~mm}$ in diameter). Then, in 1976, the first use of expanded polytetrafluoroethylene (ePTFE), also known as Teflon ${ }^{\circledR}$, was reported (Kannan et al., 2005; Chlupac et al., 2009). These prostheses are applied in the replacement of medium-sized vessels, between 6 and $10 \mathrm{~mm}$ in diameter. No studies show the superiority of PET compared to ePTFE (Roll et al., 2008). Since their introduction in cardiovascular medicine, a number of improvements have been made to enhance the performance of the synthetic vascular substitutes (SVS). Nevertheless, their low patency owing to short- and intermediate-term failure still limits their clinical application. Two of the main causes of SVS failure are thrombosis and intima hyperplasia. In-graft thrombosis is the result of a perturbation of the hemostatic balance, usually maintained by a series of anticoagulation reactions involving both physical-mechanical and biological factors, acting on the inhibition of the coagulation process (Edelberg et al., 2001). Among the different factors

\footnotetext{
${ }^{1}$ World Health Organization. Top 10 Causes of Death. Available online at: http:// www.who.int/gho/mortality_burden_disease/causes_death/top_10/en/ (accessed January 28, 2019)
}

acting in this complex balance, the intima layer, composed of endothelial cells (ECs), greatly contributes to the maintenance of the hemostatic balance by producing several antithrombotic molecules. The disruption of the endothelial layer or its absence greatly compromises the antithrombotic environment of healthy blood vessels. Intimal hyperplasia, especially at the anastomotic sites, results in the abnormal migration and proliferation of vascular smooth muscle cells (SMCs) with associated deposition of extracellular connective tissue matrix and is thought to be due to a variety of injuries that always involve some endothelial damage (Clowes, 1993). Intima hyperplasia is composed of about $20 \%$ of vascular SMCs that have migrated from the media to the intima and have proliferated and deposited extracellular matrix (ECM), which comprises most (60-80\%) of the intimal area. Normal endothelium produces factors that inhibit SMC proliferation. A damage of the endothelium layer decreases the production of growth-inhibiting factors and increases the expression of growth-stimulating factors, shifting the balance toward SMC proliferation and migration toward the intima.

As previously described, both these adverse outcomes have a common basis in the lack or uncomplete endothelialization of the implanted substitutes. Therefore, the rapid establishment of a complete and functional ECs layer on the luminal surface of SVS would be beneficial to prevent failures and for ensuring the long-term patency of the implanted substitutes.

Tissue engineering is a multidisciplinary domain aimed to develop biologically based tissues that can be used in the clinical treatments of diseases. Tissue engineering products have already shown to be effective in different applications, ranging from burn treatment to osteo-regeneration. The success obtained by this approach in other medical fields has opened the door for its use in vascular reconstruction. The use of scaffolding systems based on natural polymers is one of the strategies used in vascular tissue engineering (vTE) to promote cellular integration and proliferation. The ideal scaffold should be able to mimic the native vascular ECM and the highly complex organization of the arterial wall, showing important biological and mechanical characteristics, such as non-thrombogenicity, hemocompatibility, biocompatibility (low cytotoxicity, optimal cell adhesion, bioresorbable), and non-immunogenicity, along with tensile strength and viscoelasticity.

Among the natural polymers currently used for vTE, collagen is the most used one. Collagen is one of the main components of the vascular ECM. Its main function is to subdue constraints imposed by elongation under pressure in large vessels while providing attachment for vascular cells [12].

In this review, the main properties of the collagen molecule, along with the different types, will be presented. Moreover, collagen-based coatings will be detailed mainly in the context of vascular substitutes, and the use of collagen for the development of drug delivery systems (DDS) (with a focus on the ones with vascular applications) will be discussed. Finally, the development of in vitro physiologically relevant artery models based on collagen scaffolds for the study and validation of drugs and cardiovascular devices will be overviewed (Figure 1). 


\section{Bypass/substitution surgery for CVDs}

Synthetic substitutes:

- High rate of failure

- Low integration in host

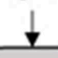

Vascular Tissue Engineering (vTE)

Natural Polymer-based approaches

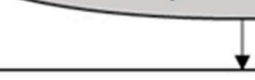

Collagen-based strategies

- Main component of vascular ECM

- Optimal biocompatibility

- Low antigenicity

- Biodegradable

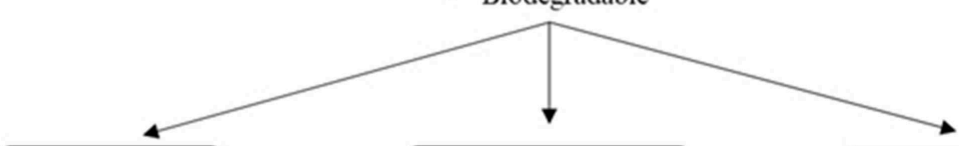

Collagen coatings

Drug delivery systems

Artificial blood vessels

- Biomimetic environment

- Pro-endothelialisation drugs

- Antibiotics

- Alternative to synthetic substitutes

- Better biological performances

- Control the porosity of substitutes

Lack of adequate mechanical properties

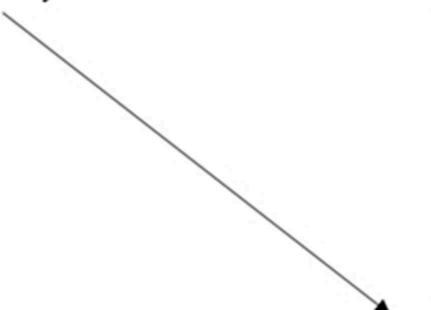

Pseudo-physiological in vitro model

- Higher complexity then in vitro models

- Avoids problems related with in vivo testing

- Highly reproducible model

Direct impact on cardiovascular medicine

FIGURE 1 | Schematic view of the layout of this review.

\section{COLLAGEN}

\section{Structure and Biosynthesis}

Collagen is the most abundant protein in animals, including the human body (Shoulders and Raines, 2009). It accounts for one third of the total protein content, and it constitutes the main component of the ECM. To date, 28 different collagen types have been identified in vertebrates, and the discovery of collagen in dinosaur bone fossils make it the oldest protein ever detected (Exposito et al., 2002; Schweitzer et al., 2007). Collagens can be divided into two main categories: fibrillar and non-fibrillar. Fibrillar collagens form elongated fibril structures, which are known for their structural role in mechanical support for most animal tissues (Hulmes, 2002; Jenkins et al., 2005; Exposito et al., 2010). Non-fibrillar collagens can be divided in sub-categories, such as network-forming collagens (collagen types IV and VII), fibril-associated collagens with interrupted triple helices (FACITs, collagen types IX and XII), and membrane-associated collagens with interrupted triple helices (MACITs). The main types of collagens, along with their distribution and composition, are listed in Table 1.

All collagens, fibrillar or not, are characterized by the same molecular structure, which is composed of three $\alpha$ chains. These chains can either be identical, thus originating a homotrimer, or be a combination of two or three distinct $\alpha$ chains forming a heterotrimer. Each $\alpha$ chain contains three basic amino acids, which are glycine, proline, and hydroxyproline, and is characterized by the presence of at least one collagenous domain, consisting of a repeating Gly-Xaa-Yaa triplet (Brazel et al., 1987), where Xaa is usually a proline and Yaa is a hydroxyproline. However, both Xaa and Yaa can be any amino acid, conferring specific functions for the collagen (Figure 2).

Fibrillar collagens are the most used in the production of collagen-based biomaterials, with type I being the most 
TABLE 1 | Main collagen types and their distribution in the human body.

\begin{tabular}{|c|c|c|c|c|}
\hline Structure & Type & Composition & Chains & Distribution \\
\hline \multirow[t]{5}{*}{$\begin{array}{l}\text { Fibrillar } \\
\text { Collagens }\end{array}$} & । & Heterotrimer & {$[\alpha 1(I)]_{2} \alpha 2(I)$} & $\begin{array}{l}\text { Skin, cornea, blood } \\
\text { vessels, bone, } \\
\text { ligaments, and tendons }\end{array}$ \\
\hline & $\|$ & Homotrimer & {$[\alpha 1(I I)]_{3}$} & $\begin{array}{l}\text { Cartilage, intervertebral } \\
\text { discs }\end{array}$ \\
\hline & III & Homotrimer & {$[\alpha 1(I I I)]_{3}$} & Skin, blood vessels \\
\hline & V & Heterotrimer & $\begin{array}{l}{[\alpha 1(V)]_{2} \alpha 2(V) \text { or }} \\
\alpha 1(V) \alpha 2(V) \alpha 3(V)\end{array}$ & $\begin{array}{l}\text { Skin, cornea, blood } \\
\text { vessels, bone, } \\
\text { ligaments, and tendons }\end{array}$ \\
\hline & $X I$ & Heterotrimer & $\alpha 1(\mathrm{XI}) \alpha 2(\mathrm{XI}) \alpha 3(\mathrm{XI})$ & $\begin{array}{l}\text { Cartilage, intervertebral } \\
\text { discs }\end{array}$ \\
\hline \multirow[t]{2}{*}{ FACITS } & IX & Heterotrimer & $\alpha 1(\mathrm{IX}) \alpha 2(\mathrm{IX}) \alpha 3(\mathrm{IX})$ & Cartilage \\
\hline & XII & Homotrimer & {$[\alpha 1(X I I)]_{3}$} & Ligaments and tendons \\
\hline \multirow{3}{*}{$\begin{array}{l}\text { Network } \\
\text { Forming }\end{array}$} & IV & Heterotrimer & {$[\alpha 1(\mathrm{IV})]_{2} \alpha 2(\mathrm{IV})$} & Basal lamina \\
\hline & VI & Heterotrimer & $\begin{array}{l}\alpha 1(\mathrm{VI}) \alpha 2(\mathrm{VI}) \alpha 3(\mathrm{VI}) \text { or } \\
\alpha 1(\mathrm{VI}) \alpha 2(\mathrm{VI}) \alpha 4(\mathrm{VI})\end{array}$ & $\begin{array}{l}\text { Bone, cartilage, } \\
\text { cornea, dermis }\end{array}$ \\
\hline & VII & Homotrimer & {$[\alpha 1(\mathrm{VII})]_{3}$} & $\begin{array}{l}\text { Under stratified } \\
\text { epithelium }\end{array}$ \\
\hline MACITS & XIII & - & - & $\begin{array}{l}\text { Endothelial cells, } \\
\text { dermis, eye, heart }\end{array}$ \\
\hline
\end{tabular}

Modified from Shoulders and Raines (2009). FACITs, fibril-associated collagens with interrupted triple helices; MACITS, membrane-associated collagens with interrupted triple helices.

abundant collagen type in the human body (Di Lullo et al., 2002). During the synthesis of fibrillar collagen molecules, alpha chains are formed by ribosomes present on the surface of rough endoplasmic reticulum (RER). These chains present registration peptides and a signal peptide that, once released in the lumen of the RER, is cleaved to form pro-collagen chains (Ishikawa and Bachinger, 2013). At this point, the pro-collagens go through several modifications (mainly hydroxylation of the lysine and proline residues and glycosylation of specific hydroxylysines) and they are finally assembled in triple helical structures. These pro-collagen triple helices are then transferred to the Golgi apparatus to be encapsulated and secreted by exocytosis. Once in the extracellular environment, the registration peptides present on the pro-collagen are cleaved and tropo-collagen is formed. Through cross-linking, several tropo-collagen molecules are assembled to produce collagen fibrils. In turn, collagen fibrils assemble to form collagen fibers (Bella and Hulmes, 2017).

\section{Collagen as a Biomaterial}

Collagen is the most used natural polymer for tissue engineering applications due to its presence in the ECM of almost every human tissue. The use of collagen as a biomaterial dates back to the early decades of the twentieth century, when the first characterization of the interaction between cells and extracted collagen was studied (Huzella and Lengyel, 1932; Ehrmann and Gey, 1956). The use of collagen is prompted by several characteristics that make it a good material for biomedical applications: Weak antigenicity and robust biocompatibility (Schmitt et al., 1964; Furthmayr and Timpl, 1976; Lee et al., 2001; Lynn et al., 2004), promotion of cell adhesion through cell receptors that recognize a specific peptide sequence within collagen molecules (Gullberg et al., 1992; Smethurst et al., 2007; Konitsiotis et al., 2008), and biodegradability (Chiang et al., 1978; Postlethwaite et al., 1978; Yannas et al., 1982). As an added value, collagen can be isolated from several sources, being one of the most abundant and best conserved proteins among vertebrates. Usual sources for collagen extractions are bovine skin and tendons (Rodrigues et al., 2003), porcine acellular bladder collagen (Chen et al., 1999), porcine collagen type I (Salamanca et al., 2018), and rat tail tendons (Ehrmann and Gey, 1956; Chandrakasan et al., 1976; Habermehl et al., 2005), but collagen has also been extracted from other organisms, such as sponges (Exposito et al., 1991), fishes (Sugiura et al., 2009), kangaroos (Johnson et al., 1999), and alligators (Wood et al., 2008), making it a cost-effective solution for scaffold-based tissue engineering.

Collagen-based biomaterials are mainly used for the treatment of burns and as wound dressing (Chattopadhyay and Raines, 2014). Due to their structure, porosity and surface properties, collagen sponges have long been used for wound dressing applications (Abramo and Viola, 1992; Fleck and Simman, 2010). Moreover, they can be loaded with therapeutic agents, such as growth factors (Lee, 2005) or antibiotics (Sripriya et al., 2004) that greatly improve the healing process once implanted. Another common application for collagen products is as an osteogenic scaffold and filling material in orthopedy (Matassi et al., 2011; Zhang et al., 2018). Collagen type I scaffolds modified with hydroxyapatite have been used as an osteochondral scaffold to improve bone and cartilage regeneration (Kon et al., 2011). Collagen scaffolds can also be used as injectable mineralized bone substitutes (Stephan et al., 2000). Next to this, collagen has been widely used for dentistry applications, such as for the production of membranes for periodontal and implant therapy to improve cell proliferation (Patino et al., 2002). Another field of application for collagen is in ophthalmology as corneal shield (Willoughby et al., 2002; Eshar et al., 2011) and as eye implants for post-operative recovery (Delarive et al., 2003) and corneal implantation (Liu et al., 2006). Finally, the use of collagen as a scaffold for the development of a DDS has attracted the attention of many researchers all over the world (Wallace and Rosenblatt, 2003) for several applications, such as bone regeneration, eye, cardiac, and brain medicine (Lucas et al., 1989; Kaufman et al., 1994; Chiu et al., 2010; Chan et al., 2017) since the 1970s (Bradley and Wilkes, 1977).

\section{Functionalization of Collagen for Tissue Engineering Applications}

One of the most important limitations in using collagen-based materials in regenerative medicine applications remains their mechanical properties, which are often limited, especially at the viscoelastic level, specifically, for vTE, mechanical properties related to the high pressures and stresses encountered in the blood vessel (Achilli et al., 2010; Meghezi et al., 2015). Research has therefore focused on various ways of enhancing and controlling the polymerization, the stability in solutions, reducing enzymatic sensitivity, and controlling the pore size, in an attempt to increase mechanical strength. An 


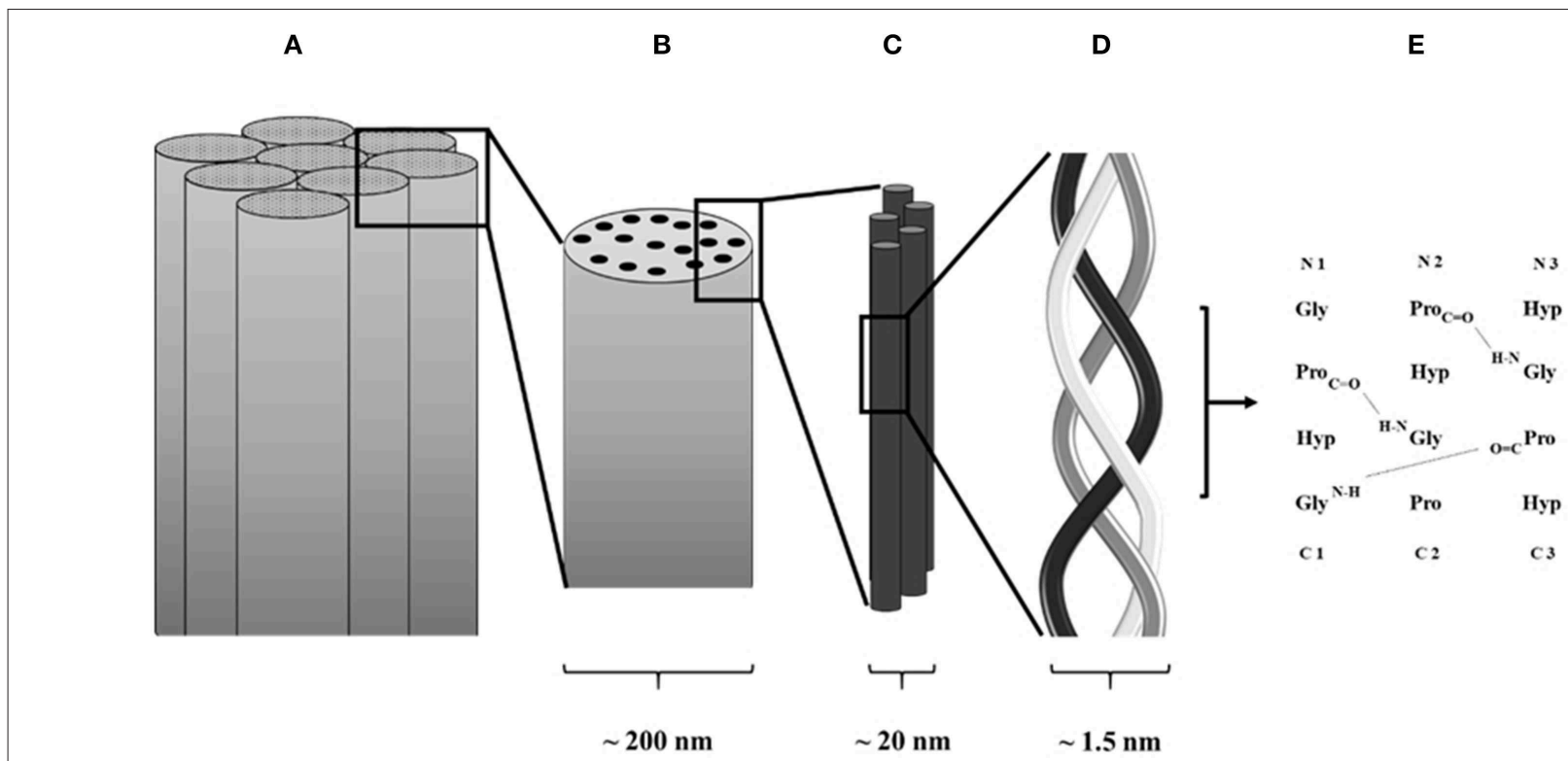

FIGURE 2 | Schematic collagen structure. (A) Collagen fiber formed by assembled collagen fibrils. (B) Collagen fibrils. (C) Assembled tropocollagen. (D) Collagen triple helix. (E) Hydrogen bond in between collagen $\alpha$ chains.

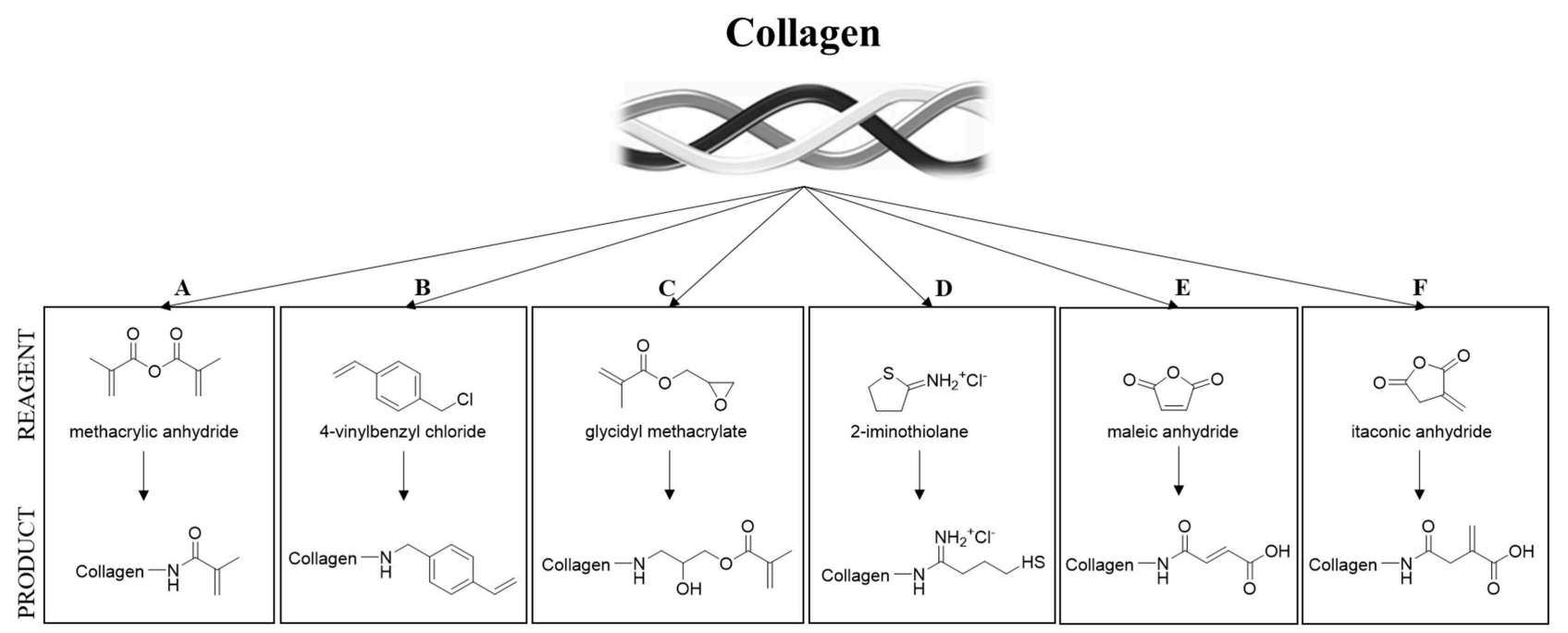

FIGURE 3 | Strategies for collagen functionalization. (A) Methacrylic anhydride (Gaudet and Shreiber, 2012; Pupkaite et al., 2017); (B) 4-vinylbenzylchloride and (C) glycidyl methacrylate (Tronci et al., 2013); (D) thiol-functionalization (Holmes et al., 2017) and (E,F) unsaturated cyclic anhydrides (Potorac et al., 2014).

interesting approach to maintain the structural integrity of a scaffold is to chemically, physically, or enzymatically cross-link the biopolymer (Davidenko et al., 2015; Liu et al., 2019). However, collagen has a limited number of functional groups (i.e., amine and carboxylic acids) that can enable cross-linking (Gallop and Paz, 1975; Rýglová et al., 2017). For this reason, cross-linkable modifications have been introduced on the protein structure (Ravichandran et al., 2016) (Figure 3). An overview of various types of modified collagen is shown in Table 2.

\section{COLLAGEN IN vTE}

Collagen Coatings for Vascular Substitutes

One of the main complications related to the use of synthetic vascular grafts, and especially with the ones made of PET (Dacron), is linked to their high porosity and low elasticity. While porosity allows tissue ingrowth, ensuring a physiological integration of the implanted grafts, and a faster healing, it also causes excessive bleeding, inducing potential serious complications for the patients. Thus, the walls of the grafts must 
TABLE 2 | Overview on various functional groups that have been introduced on the collagen backbone.

\begin{tabular}{|c|c|c|c|c|}
\hline Material & Functional group & Aim of the modification & Figure & References \\
\hline Collagen Type I & Methacrylate & Sutureless wound closure & A & Pupkaite et al., 2017 \\
\hline Collagen Type I & Methacrylate & Mechanically heterogeneous environments & A & Gaudet and Shreiber, 2012 \\
\hline Collagen Type I & $\begin{array}{l}\text { 4-vinylbenzyl chloride (4VBC) } \\
\text { and glycidyl methacrylate (GMA) }\end{array}$ & $\begin{array}{l}\text { Programmable macroscopic } \\
\text { properties }\end{array}$ & $\mathrm{B}, \mathrm{C}$ & Tronci et al., 2013 \\
\hline Collagen Type I & $\begin{array}{l}\text { 8-arm poly (ethylene glycol) norbornene-terminated } \\
\text { (PEG-NB) }\end{array}$ & $\begin{array}{l}\text { Injectable regenerative } \\
\text { hydrogels }\end{array}$ & $\mathrm{D}$ & Holmes et al., 2017 \\
\hline Collagen Type I + III & Cyclic anhydrides & Mechanical performance enhancement & $E, F$ & Potorac et al., 2014 \\
\hline
\end{tabular}

be rendered impermeable in order to avoid this outcome. For this reason, pre-clotting is a mandatory clinical step prior to the implantation of a Dacron (PET knitted or woven) graft. This technique consists in the conversion of the porous wall of the prosthesis into one that has been rendered impervious by reaction with blood (Yates et al., 1978). Despite helping in limiting bleeding, this technique is hampered by several disadvantages, such as the increase of the roughness of the luminal surface of the implanted grafts. This rougher surface increases the occurrence of turbulent blood flow and thrombus formation, and the increase in the rigidity of the graft straightforwardly diminishes their pliability.

The impregnation of porous Dacron vascular grafts with collagen was first proposed in the early 1960s (Humphries et al., 1961) as an alternative to pre-clotting. Striking improvements were obtained years later by Scott and colleagues in 1987 (Scott et al., 1987). Their bovine collagen-coated grafts did not require pre-clotting or special preparation and did not bleed once implanted in a canine model. The luminal surface of the grafts showed neointima formation, and the collagen coating was completely resorbed and substituted by native tissue after 3 months of implantation. Moreover, the collagen was nonthrombogenic or antigenic. That opened the door for the use of collagen-impregnated vascular grafts in the surgical treatment of aneurysms and for arterial bypass (Reigel et al., 1988; Freischlag and Moore, 1990; Noishiki et al., 1996), proving to be a viable alternative to the previously used pre-clotting technique, being able to compete equally against other proposed techniques and materials (Prager et al., 2003).

Nonetheless, these collagen-coated grafts have been demonstrated over the years not to be free from complications: Variable inflammatory response and tissue adhesion (Jonas et al., 1987), need of sustained chest drainage (Suehiro et al., 2003), and initiation of the immune response (Kobayashi et al., 1993) in the treated patients. Moreover, they showed no added value for the replacement of small-caliber arteries (Guidoin et al., 1996). However, the performances of the collagen-coated vascular grafts have stood the test of time, resulting in being one of the most used vascular grafts for medium- and large-diameter arteries substitution nowadays.

\section{Collagen-Based DDS}

Biological signaling represents an important point in cell-driven tissue regeneration and providing signaling molecules greatly improves this process. However, when administering molecules and drugs, it is of crucial importance to reach the appropriate dose at a specific site and for the necessary period of time, in order to accomplish the desired effects. Thus, there is a need to release these molecules in a controlled way.

The development of collagen-based DDS for the release of pro-angiogenetic factors for wound healing applications and proendothelialization factors for vascular implant functionalization is highly sought after. Collagen has been widely studied as a biomaterial for DDS (Friess, 1998) and has found several uses in a variety of applications (Table 3 ).

The use of collagen-based DDS for vascular applications has been explored in recent years. Most of the studies performed aimed to increase the affinity for the collagen scaffolds toward ECs. The enrichment of collagen matrices with several proangiogenetic growth factors, such as vascular endothelial growth factor (VEGF) (Steffens et al., 2004; Koch et al., 2006; He et al., 2011), stromal derived factor-1 alpha (SDF-1 $\alpha$ ) (Laiva et al., 2018), and basic fibroblast growth factor (bFGF) (Hao et al., 2018), has shown promising results in terms of controlling the release of the loaded molecules and the angiogenesis induction, which in turn results in compelling effects during wound repair and for tissue engineering applications.

As mentioned in the Introduction, the use of synthetic vascular grafts for the treatment of occlusive vascular diseases is still a burden by grafts failure, mainly caused by thrombosis and neointima hyperplasia. Implants modifications using proendothelialization molecules and growth factors with the aim of speeding up the re-endothelialization process have been proposed over the last years to guide the optimal integration of the grafts and to overcome the aforementioned problems. The use of vascular graft enrichment has also been investigated. In their work from 2000, Wissink et al. developed a heparinized, cross-linked collagen matrix for the controlled release of bFGF to improve the endothelialization of vascular grafts (Wissink et al., 2000). They were able to improve the binding of the loaded bFGF to the heparinized cross-linked matrix and to release it in a controlled way over time, leading to an improvement in the proliferation of treated EC in vitro.

The occurrence of infections in newly implanted synthetic vascular grafts is one of the complications that may arise, hampering the functionality of the prosthesis. Conventional treatments of vascular graft infections consist in the excision of the infected graft with extra anatomic bypass grafting (Yeager et al., 1999). To avoid the need of another surgical operation to treat the infected grafts, the use of DDS has 
TABLE 3 | Collagen-based drug delivery systems.

\begin{tabular}{|c|c|c|c|c|c|}
\hline & Scaffold structure & Medical application & Biomolecule used & Cells seeded & References \\
\hline \multirow[t]{3}{*}{ Growth factors/Drugs } & Collagen sponges & Wound healing & VEGF & / & Schroeder et al., 2007 \\
\hline & Collagen sponges & Tissue regeneration & $\begin{array}{l}\text { bFGF, HGF, } \\
\text { PDGF-BB, VEGF, } \\
\text { IGF-1, HB-EGF }\end{array}$ & / & Kanematsu et al., 2004 \\
\hline & & Antibacterial & Gentamicin & / & Ivester et al., 2006 \\
\hline \multirow[t]{4}{*}{ Cells } & Electrospun collagen & Bone & / & BM-MSC & Shih et al., 2006 \\
\hline & $\begin{array}{l}\text { Collagen-glycosaminoglycans } \\
\text { scaffold }\end{array}$ & Cardiovascular & / & BM-MSC & Xiang et al., 2006 \\
\hline & Collagen sponges & Brain & / & NSC & Yu et al., 2010 \\
\hline & $\begin{array}{l}\text { Collagen sponges and } \\
\text { hydrogels }\end{array}$ & Intervertebral discs & / & $\begin{array}{l}\text { Human intervertebral } \\
\text { disc cells }\end{array}$ & Gruber et al., 2004, 2006 \\
\hline
\end{tabular}

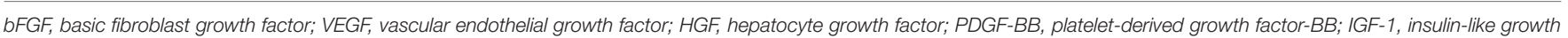
factor-1; HB-EGF, heparin binding epidermal growth factor-like growth factor; BM-MSC, bone marrow mesenchymal stem cells; NSC, neural stem cells.

been proposed. In particular, collagen-based matrices have been demonstrated to be effective in delivering antibiotic agents to limit and treat bacterial infections in implanted synthetic vascular grafts (Chervu et al., 1991; Batt et al., 2003; Schneider et al., 2008; Herten et al., 2017), avoiding the need for subsequent surgical interventions.

\section{Collagen Scaffolds for Vascularization and Artificial Blood Vessel Development}

Over the years, collagen has been used as a pro-vascularization scaffold for several applications. In fact, the ability of collagen scaffolds to support angiogenesis and the formation of neovasculature has been demonstrated (Nicosia et al., 1991). Collagen scaffolds have been first used as an in vitro model for the study of the angiogenetic process (Vernon et al., 1995), but their use has been shortly translated to the clinic (Abraham et al., 2000) for several applications. In 2008, Shen et al. showed how a VEGF-modified collagen scaffold was able to efficiently promote penetration, proliferation, and assembly of ECs in the scaffold (Shen et al., 2008). In 2016, Chan and colleagues developed a 3D scaffold from bovine collagen type I able to support capillary formation in vivo and vascularization once implanted in animal models (Chan et al., 2016). Similarly, other groups demonstrated how implanted collagen scaffolds were able to promote EC infiltration and vascularization (Cherubino et al., 2016; Wahl et al., 2016). Interestingly, the joint use of other ECM components along collagen, like elastin or glycosaminoglycans, has been shown to exert different effects on the vascularization of collagen scaffolds (Schmidt et al., 2017).

Collagen is one of the most abundant proteins in the vascular ECM. There, collagen fibers limit the distension of the vessel and provide attachment for SMCs, allowing them to transmit circumferential forces to the vessel wall, ultimately conferring excellent mechanical support to the blood vessel wall (BouGharios et al., 2004). Therefore, the use of collagen, in particular type I, as a scaffold in the development of tissue-engineered vascular substitutes has been largely explored. The first use of collagen gels to manufacture a vascular substitute dates back to 1986, when Weinberg and Bell attempted to reconstitute a blood vessel (Weinberg and Bell, 1986). Their method consisted in the production of a multilayered tubular construct made of collagen seeded with SMCs and fibroblasts and of the endothelialization of its lumen. Despite showing very low mechanical properties and the impossibility to be used for clinical purposes, this work marked a major advance in the field of vTE, with several groups following in the footsteps (Hirai et al., 1994; Seliktar et al., 2000; Boccafoschi et al., 2007) and trying to improve the system. One of the main problems related to this kind of construct is its mechanical properties. Different variants of the methodology from Weinberg and Bell, such as winding leaflets around a mandrel to promote compaction of collagen (L'Heureux et al., 1993), magnetic pre-alignment of collagen fibers to increase tensile strength (Tranquillo et al., 1996), cross-linking of collagen scaffolds by glycation (Girton et al., 2000), or ultraviolet radiation (Charulatha and Rajaram, 2003) have been developed to improve the mechanical properties of the substitutes. However, the extent of these improvements still does not allow the implantation and, thus, the use in the medical practice of these grafts. The seeded cells play an important role too: SMCs have been demonstrated to actively influence the compaction of the collagen scaffold (Berglund et al., 2003; Meghezi et al., 2015) and to align along the direction of the collagen fibers (Hirai et al., 1994), helping in increasing the mechanical properties of the substitutes. The biological properties have also been studied. Different molecules have been used to modulate the cellular response toward these scaffolds. The addition of insulin and growth factors, such as TGF- $\beta$ makes it possible to increase collagen production by the seeded cells (Long and Tranquillo, 2003), and the addition of dermatan sulfate has been able to increase the endothelialization of the lumen and, as a result, to reduce platelet adhesion and activation (Matsuda et al., 1988). In recent years, hybrid collagen vascular substitutes containing both synthetic (He et al., 2005; Stitzel et al., 2006; Jeong et al., 2007) and natural polymers, such as fibrin (Cummings et al., 2004) and elastin in particular (Berglund et al., 2004; Koens et al., 2010, 
2015), have been developed to further increase the mechanical and biological properties of the collagen-based vascular grafts, aiming to obtain an artificial vessel as close as possible to the natural ones.

\section{Pre-clinical and Clinical Studies of Collagen for vTE Applications}

As of today, the main use of collagen for clinical applications is as replacement scaffolds (i.e., tissue fillers) and as support matrices (i.e., matrix rich tissues). Collagen scaffolds used in clinical practice primarily include skin substitutes and dermal fillers. However, the use of collagen for other applications, including vascular applications, is increasing. In fact, a number of positive factors indicate that the use of a collagenbased product is becoming an attracting prospective for vTE purposes (Dogan et al., 2017). Table 4 shows some of the pre-clinical studies conducted on collagen-based vTE products. It can be observed that collagen-based materials for vascular applications, especially for vascular grafts, are successfully used in pre-clinical studies involving in vivo testing and, therefore, physiological stimulation. It can be concluded that research in the field is moving toward the achievement of those optimal properties needed for the clinical translation.

\section{COLLAGEN-BASED PSEUDO-PHYSIOLOGICAL MODELS FOR CARDIOVASCULAR THERAPY DEVELOPMENT}

\section{Development of 3D in vitro Models for Cardiovascular Research}

Although tissue-engineered blood vessels as living arterial substitutes have been studied extensively in the last 25 years, clinical translation has not yet happened (Zhang et al., 2007; Nemeno-Guanzoni et al., 2012). The mechanism by which these grafts integrate into the host's circulatory system and remodel into functional blood vessels remains unclear (Pashneh-Tala et al., 2016). Despite this drawback, the vTE grafts can be used as an advanced model of the vascular wall for the in vitro testing of drugs and devices. In fact, currently used in vitro pre-clinical models represent an overly simplified vascular environment, not able to reproduce the complex cell-cell and cell-environment interactions taking place in vivo. On the other hand, in vivo animal models currently used for the development of medical drugs and devices show limitations and disadvantages, such as animal-to-human variations in anatomy, physiology, and functions together with high costs and ethical burden (Byrom et al., 2010; Swartz and Andreadis, 2013). The four main factors to consider in order to develop a successful in vitro vascular wall model are as follows: (i) a scaffold that can support cell growth, (ii) an appropriate cell population, (iii) the right biological (use of biomolecules, such as growth factors), and (iv) mechanical stimuli to influence the proper development of the construct (Fortunato et al., 2017). Different research groups have been working with the final aim to develop in vitro models able to finely mimic the wall structure of a healthy human artery. Some examples of the development in in vitro models, based on different approaches, can be found in Table 5.

Collagen is widely used for the development of physiologically relevant in vitro models (Boccafoschi et al., 2005; Seifu et al., 2013; Pawelec et al., 2016). One of the main challenges in developing an in vitro vascular wall model is the interaction between the different populations of cells (Battiston et al., 2014). Loy et al. $(2016,2018)$ developed an in vitro model of the vascular wall based on collagen gels cellularized with SMCs, fibroblasts, and ECs. In this study, the importance of co-culturing these three vascular cell types in order to promote cell-matrix remodeling and to obtain an early expression of elastic fiberrelated proteins was stressed. Furthermore, it was shown that the use of a tri-culture model resulted in cell-cell interactions similar to in vivo conditions. Another challenge in the development of advanced in vitro vascular models, as for vTE grafts, is the improvement of mechanical properties (i.e., compliance, burst pressure, and elasticity) and an increase in complexity of the model. Pezzoli et al. (2018) developed a collagen-based in vitro model that was supplemented with human plasma fibronectin. This resulted in an increase in elastin deposition by SMCs, as well as an increase in the expression levels of several proteins required for elastogenesis (i.e., fibrillin-1, lysyl oxidase, fibulin4 , and latent TGF- $\beta$ binding protein-4). The study showed how fibronectin plays a crucial role in the production of physiologicallike, elastin-containing collagen matrices displaying superior mechanical properties compared to the currently used models. It has been shown that in vitro simulation of physiological biochemical and biomechanical conditions plays a crucial role in the development of a physiologically relevant model of the vascular wall. To achieve this, research has focused on different strategies, including the use of bioreactors (Bono et al., 2017; Tresoldi et al., 2017). Bioreactors have gained large interest because they provide the possibility to mimic a physiological environment similar to the human in vivo situation, allowing the improvement of both mechanical and biological properties of in vitro models (Arslan-Yildiz et al., 2016; Tresoldi et al., 2017; Loy et al., 2018). The physiological-like mechanical stimulation is of utmost importance in the development of an engineered model of the vascular wall. The applied hemodynamic forces can lead to improvements in the structural and mechanical properties of the engineered construct. This is mainly due to an increased circumferential orientation of the SMCs and the alignment of the ECs along the flow direction, leading to a higher yield stress, ultimate stress, and elastic modulus (Ziegler et al., 1995; Tresoldi et al., 2017). Moreover, the simulation of physiological pulsatile perfusion improves not only the artificial vascular development in terms of cell alignment and organization (Houtchens et al., 2008; Lesman et al., 2016; Asano et al., 2018), but also the cell differentiation and phenotypic maintenance (Cevallos et al., 2006; Li and Xu, 2007; Qiu et al., 2014), ECM production (Stanley et al., 2000; Halka et al., 2008), vascular tone (Garoffolo et al., 2018), and mechanical properties (Seliktar et al., 2000) of the engineered construct (Meghezi et al., 2012; Wissing et al., 2017; Colunga and Dalton, 2018). 
TABLE 4 | Pre-clinical and clinical studies on collagen-based vascular tissue engineering products.

\begin{tabular}{|c|c|c|c|c|}
\hline Material & Structure & Application & Implanted in & References \\
\hline Bovine collagen type I & Porous collagen scaffolds & Tissue vascularization & Murine model (C57B/L6 mice) & Chan et al., 2016 \\
\hline Rat tail type I collagen & Dense gel tubes & $\begin{array}{l}\text { Small-diameter vascular } \\
\text { grafts }\end{array}$ & Murine model (Sprague-Dawley rats) & Li et al., 2017 \\
\hline Autologous collagen matrix & $\begin{array}{l}\text { in vivo tissue-engineered } \\
\text { autologous vascular graft }\end{array}$ & $\begin{array}{l}\text { Pediatric pulmonary artery } \\
\text { augmentation }\end{array}$ & $\begin{array}{l}\text { Human model (2-years-old girl with } \\
\text { pulmonary atresia) }\end{array}$ & Kato et al., 2016 \\
\hline Collagen type I and type III & Porous collagen membranes & Myocardial ischemia repair & Rabbit model & Gao et al., 2011 \\
\hline
\end{tabular}

TABLE 5 | Vascular tissue-engineered in vitro models and strategies used.

\begin{tabular}{|c|c|c|}
\hline Developed model & Strategy & References \\
\hline Planar vessel wall model & Collagen type I hydrogel & Loy et al., 2016 \\
\hline $\begin{array}{l}\text { Tissue-engineered vascular } \\
\text { equivalent }\end{array}$ & $\begin{array}{l}\text { Polyglycolic-acid (PGA) } \\
\text { meshes }\end{array}$ & Robert et al., 2013 \\
\hline $\begin{array}{l}\text { Tubular vascular model for } \\
\text { inflammatory response } \\
\text { analysis }\end{array}$ & Collagen type I Scaffold & Chen et al., 2018 \\
\hline Micro-vascular networks & 3-D printing approach & Schoneberg et al., 2018 \\
\hline
\end{tabular}

\section{Currently Used Collagen-Based in vitro Models for CVDs and Drug Development Studies}

Medical drugs that contribute to blood pressure elevation or reduction can have a great efficacy in reducing cardiovascular risks (Cameron et al., 2016). Vasodilation and vasoconstriction directly affect the blood vessel diameter and thus an increased or decreased blood flow; therefore, they have an immediate impact on the blood pressure (Toda et al., 2013). More than $80 \%$ of currently proposed pharmaceutical drug candidates that enter clinical trials fail due to concerns with human efficacy and toxicity (Fernandez et al., 2016). Animal responses to drugs exhibit differences in toxic doses and drug metabolism. Therefore, the development of in vitro models that accurately mimic specific biological interactions, particularly relevant to diseases, using human cells to be able to predict local responses to administered drugs is of critical importance (Truskey and Fernandez, 2015; Fernandez et al., 2016; Ronaldson-Bouchard and Vunjak-Novakovic, 2018). For example, it is known that the SMCs in the media layer of the vascular wall are fundamental for the regulation of the vascular tone, being a key factor in the contractile portion of the vascular wall (Wolf et al., 2016). Next to this, the ECs layer exerts important effects on the vascular tone too, mainly through the release of vasoconstrictor and vasodilator molecules (Toda et al., 2013). Vaso-activity, being the vascular activity involving the effect of either increasing or decreasing blood pressure and/or heart rate, is considered an important feature and a desirable characteristic for a tissueengineered model. It is influenced by many factors including cell phenotype and cell-matrix interactions. Different models have been developed over the years. The group of Laflamme (Laflamme et al., 2005) made use of a simple SMC-based media layer for studying the vaso-reactive properties, whereas
Fernandez et al. (2016) and Niklason et al. (1999) fabricated a model based on a media layer combined with an EC layer to mimic the vessel intima layer.

Fernandez et al. (2016) validated the use of non-destructive monitoring strategies on collagen-based vascular constructs. This strategy helped in discovering that acetylcholine, which stimulates the release of nitric oxide, prostacyclin, and endothelium-derived hyperpolarization factor in vessels with a healthy and intact endothelium, is an important vasodilator in coronary arteries, enabling the quantification of endothelium-dependent vasodilation. On the other hand, phenylephrine enables the non-destructive measure of endothelium-independent vasoconstriction. The group of Schutte has studied the functionality of collagen-based engineered vascular media layers by looking at a large panel of vasoactive agents that consists of drugs from both intrinsic and extrinsic pathways (Schutte et al., 2010b). The study has shown that the collagen-based models were capable of generating a measurable response to several different vasoconstrictors and vasodilators. They highlighted the importance of vaso-activity and the functionality of developed models, as well as the choice of a large panel of drugs to test both features. In their work from 2016, Wolf et al. gave an overview on different engineered vascular constructs studied for pharmacological studies (Wolf et al., 2016). These studies demonstrate that TE vascular constructs can be used as in vitro models to investigate pharmacologically induced responses. However, these studies have currently been done on simplified models of the vascular wall using only the media and intima layer. Further research on the evaluation of the effects of vaso-reactive stimuli on a more advanced, complex, and physiologically relevant model of the vascular wall is yet to be studied. It can be concluded that in vitro models of the vascular wall show great potential and importance in the study of CVD and treatment, both at pre-clinical and clinical stages.

\section{DISCUSSION}

\section{Strengths, Weaknesses, Opportunities, and Threats of Collagen as a Biomaterial for VTE}

Despite the multiple beneficial properties and the variety of proposed applications in vTE described in this review, the use of collagen in vascular medicine is still hampered by some problems. The strength, weaknesses, opportunities, and threats (SWOT) 


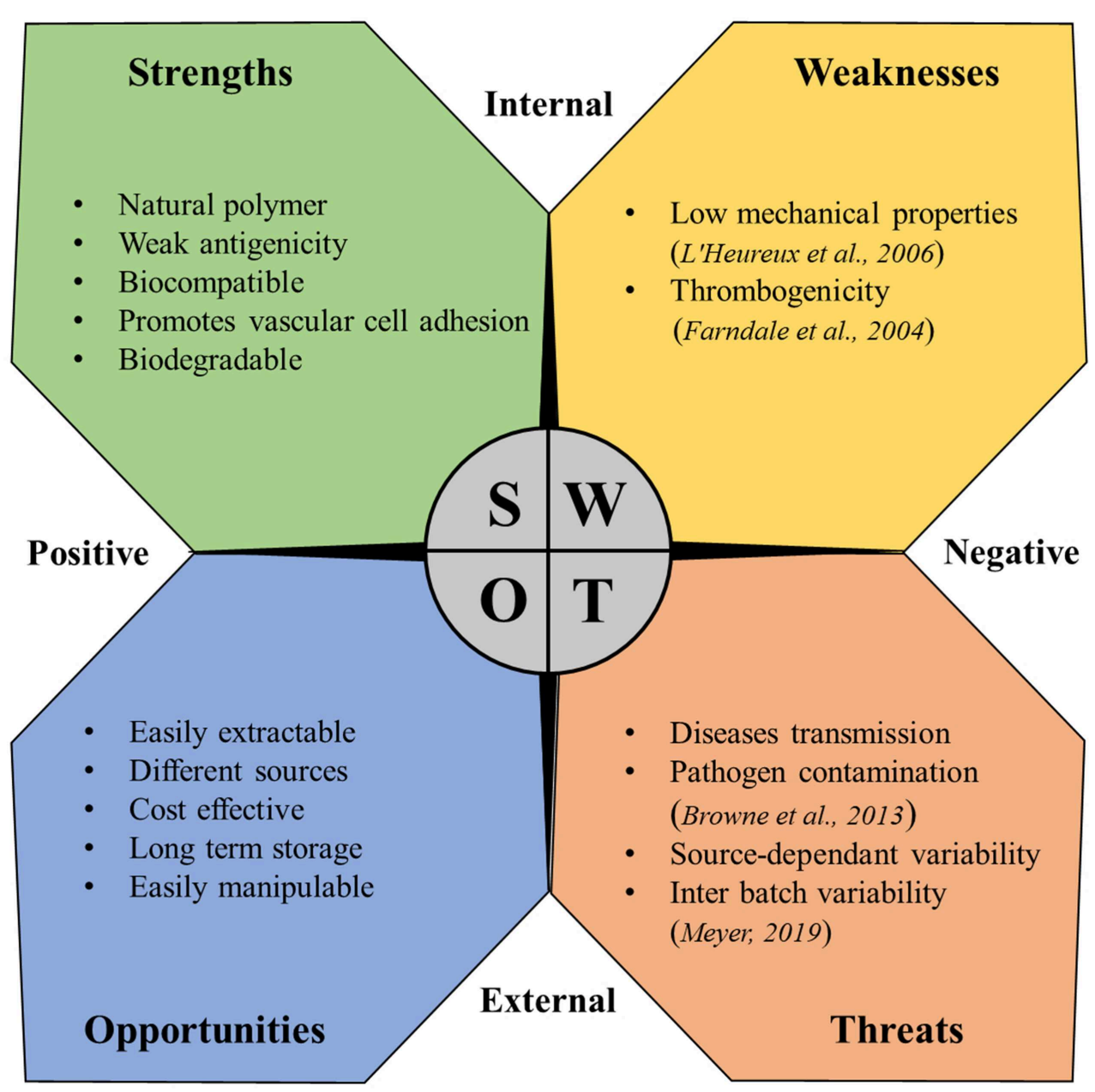

FIGURE 4 | SWOT analysis for collagen as a material for vascular tissue engineering (Farndale et al., 2004; L'Heureux et al., 2006; Browne et al., 2013; Meyer, 2019).

analysis represented in Figure $\mathbf{4}$ summarizes the benefits and the main problems and concerns related to the use of collagen in this field.

\section{Limits of Collagen}

As mentioned in the SWOT analysis, two main limits heavily hamper the use of collagen in vTE: collagen thrombogenicity and its poor mechanical properties. Especially for applications where blood contact plays a major role like in vTE, collagen intrinsic thrombogenicity represents a major limitation. In fact, collagen is known to be one of the major activators of platelet response, being able to trigger and support both platelet adhesion and activation (Farndale et al., 2004), thus impacting the thrombogenicity of vascular devices. Thrombogenic potential, especially for vascular graft, is a major issue, being responsible for earlier graft occlusion (Sarkar et al., 2007). Thus, the use of collagen has been addressed for these reasons (Guidoin et al., 1996). Modification of the collagen through bonding of antithrombotic agents, such as heparin has been proposed over the years (Keuren et al., 2004; Scharn et al., 2006; Al Meslmani et al., 2014), partially solving the issue but leaving an open problem. Collagen plays a major role for in vivo vascular stiffness, conferring mechanical resistance along with the other molecules of the vascular ECM. However, extraction processes critically compromised the mechanical strength of collagen. As a consequence, low mechanical properties are reported as one of the main problems related to collagen for vTE (L'Heureux et al., 2006), thus limiting its clinical application. Over the years, improvements have been shown through dynamic conditioning (Seliktar et al., 2000; Buttafoco et al., 2006; Schutte et al., 2010a) or enhanced cross-linking techniques (Brinkman et al., 2003). Unfortunately, although these are promising techniques, all reported cases in the literature show ultimate mechanical properties significantly below those of native blood vessels (Pashneh-Tala et al., 2016), once again showing the difficulties in the clinical translation.

\section{CONCLUSIONS AND OUTLOOK}

Collagen-based scaffolds have been proven to be a versatile biomaterial for vascular applications, gaining great achievements in vTE. Although collagen is complex by nature, its use allowed 
great developments in implants and drug delivery and offers great opportunities in several fields of tissue engineering, for dermal, cardiovascular, and connective applications. From a scientific point of view, the open challenge remains to be able to reproduce the hierarchically complex nature of tissues starting from collagen. In fact, in living tissue, a number of biologically active molecules, proteins, and cells work together in a very dynamic environment continuously orchestrating regeneration. From an industrial point of view, although some companies are now able to extract, sterilize, de-immunize, neutralize, and finally provide different types of collagen in a reproducible manner, its cost remains prohibitive and seriously limits studies and developments in the field. Therefore, the open challenges remain to find alternative sources and to optimize processes

\section{REFERENCES}

Abraham, G. A., Murray, J., Billiar, K., and Sullivan, S. J. (2000). Evaluation of the porcine intestinal collagen layer as a biomaterial. J. Biomed. Mater. Res. 51, 442-452. doi: 10.1002/1097-4636(20000905) 51:3<442::AID-JBM19>3.0.CO;2-4

Abramo, A. C., and Viola, J. C. (1992). Heterologous collagen matrix sponge: histologic and clinical response to its implantation in third-degree burn injuries. Br. J. Plast. Surg. 45, 117-122. doi: 10.1016/0007-1226(92)90170-3

Achilli, M., Lagueux, J., and Mantovani, D. (2010). On the effects of UV-C and $\mathrm{pH}$ on the mechanical behavior, molecular conformation and cell viability of collagen-based scaffold for vascular tissue engineering. Macromol. Biosci. 10, 307-316. doi: 10.1002/mabi.200900248

Al Meslmani, B., Mahmoud, G., Strehlow, B., Mohr, E., Leichtweiss, T., and Bakowsky, U. (2014). Development of thrombus-resistant and cell compatible crimped polyethylene terephthalate cardiovascular grafts using surface coimmobilized heparin and collagen. Mater. Sci. Eng. C. Mater. Biol. Appl. 43, 538-546. doi: 10.1016/j.msec.2014.07.059

Arslan-Yildiz, A., El Assal, R., Chen, P., Guven, S., Inci, F., and Demirci, U. (2016). Towards artificial tissue models: past, present, and future of $3 \mathrm{D}$ bioprinting. Biofabrication 8:014103. doi: 10.1088/1758-5090/8/1/014103

Asano, S., Ito, S., Morosawa, M., Furuya, K., Naruse, K., Sokabe, M., et al. (2018). Cyclic stretch enhances reorientation and differentiation of 3-D culture model of human airway smooth muscle. Biochem. Biophys. Rep. 16, 32-38. doi: 10.1016/j.bbrep.2018.09.003

Batt, M., Magne, J. L., Alric, P., Muzj, A., Ruotolo, C., Ljungstrom, K. G., et al. (2003). In situ revascularization with silver-coated polyester grafts to treat aortic infection: early and midterm results. J. Vasc. Surg. 38, 983-989. doi: 10.1016/S0741-5214(03)00554-8

Battiston, K. G., Cheung, J. W., Jain, D., and Santerre, J. P. (2014). Biomaterials in co-culture systems: towards optimizing tissue integration and cell signaling within scaffolds. Biomaterials 35, 4465-4476. doi: 10.1016/j.biomaterials.2014.02.023

Bella, J., and Hulmes, D. J. (2017). Fibrillar collagens. Subcell. Biochem. 82, 457-490. doi: 10.1007/978-3-319-49674-0_14

Berglund, J. D., Mohseni, M. M., Nerem, R. M., and Sambanis, A. (2003). A biological hybrid model for collagen-based tissue engineered vascular constructs. Biomaterials 24, 1241-1254. doi: 10.1016/S0142-9612(02)00506-9

Berglund, J. D., Nerem, R. M., and Sambanis, A. (2004). Incorporation of intact elastin scaffolds in tissue-engineered collagen-based vascular grafts. Tissue Eng. 10, 1526-1535. doi: 10.1089/ten.2004.10.1526

Boccafoschi, F., Habermehl, J., Vesentini, S., and Mantovani, D. (2005). Biological performances of collagen-based scaffolds for vascular tissue engineering. Biomaterials 26, 7410-7417. doi: 10.1016/j.biomaterials.2005.05.052

Boccafoschi, F., Rajan, N., Habermehl, J., and Mantovani, D. (2007). Preparation and characterization of a scaffold for vascular tissue engineering by directassembling of collagen and cells in a cylindrical geometry. Macromol. Biosci. 7, 719-726. doi: 10.1002/mabi.200600242 and protocols for reliable, reproducible, safe, and low-cost collagen. Finally, accreditation and regulatory bodies are the missed elements in this complex equation. The idea to synthesize collagen in laboratory is an idea worthy to be further explored and that will also facilitate the regulation concerning the collagen structures, in the interest of the patients, and for the benefit of the society.

\section{AUTHOR CONTRIBUTIONS}

FC and DM conceived the layout, the rationale, and the plan of this manuscript. FC and NP wrote the first draft of the manuscript that was iteratively improved by SV, $\mathrm{FB}$, and DM.

Bono, N., Meghezi, S., Soncini, M., Piola, M., Mantovani, D., and Fiore, G. B. (2017). A dual-mode bioreactor system for tissue engineered vascular models. Ann. Biomed. Eng. 45, 1496-1510. doi: 10.1007/s10439-017-1813-9

Bou-Gharios, G., Ponticos, M., Rajkumar, V., and Abraham, D. (2004). Extra-cellular matrix in vascular networks. Cell Prolif. 37, 207-220. doi: 10.1111/j.1365-2184.2004.00306.x

Bradley, W. G., and Wilkes, G. L. (1977). Some mechanical property considerations of reconstituted collagen for drug release supports. Biomater. Med. Devices Artif. Organs 5, 159-175. doi: 10.3109/10731197709118671

Brazel, D., Oberbaumer, I., Dieringer, H., Babel, W., Glanville, R. W., Deutzmann, R., et al. (1987). Completion of the amino acid sequence of the alpha 1 chain of human basement membrane collagen (type IV) reveals 21 non-triplet interruptions located within the collagenous domain. Eur. J. Biochem. 168, 529-536. doi: 10.1111/j.1432-1033.1987.tb13450.x

Brinkman, W. T., Nagapudi, K., Thomas, B. S., and Chaikof, E. L. (2003) Photo-cross-linking of type I collagen gels in the presence of smooth muscle cells: mechanical properties, cell viability, and function. Biomacromolecules 4, 890-895. doi: 10.1021/bm0257412

Browne, S., Zeugolis, D. I., and Pandit, A. (2013). Collagen: finding a solution for the source. Tissue Eng. Part A 19, 1491-1494. doi: 10.1089/ten.tea.2012.0721

Buttafoco, L., Engbers-Buijtenhuijs, P., Poot, A. A., Dijkstra, P. J., Vermes, I., and Feijen, J. (2006). Physical characterization of vascular grafts cultured in a bioreactor. Biomaterials 27, 2380-2389. doi: 10.1016/j.biomaterials.2005.10.017

Byrom, M. J., Bannon, P. G., White, G. H., and Ng, M. K. (2010). Animal models for the assessment of novel vascular conduits. J. Vasc. Surg. 52, 176-195. doi: 10.1016/j.jvs.2009.10.080

Cameron, A. C., Lang, N. N., and Touyz, R. M. (2016). Drug treatment of hypertension: focus on vascular health. Drugs 76, 1529-1550. doi: 10.1007/s40265-016-0642-8

Cevallos, M., Riha, G. M., Wang, X., Yang, H., Yan, S., Li, M., et al. (2006). Cyclic strain induces expression of specific smooth muscle cell markers in human endothelial cells. Differentiation 74, 552-561. doi: 10.1111/j.1432-0436.2006.00089.x

Chan, E. C., Kuo, S. M., Kong, A. M., Morrison, W. A., Dusting, G. J., Mitchell, G. M., et al. (2016). Three dimensional collagen scaffold promotes intrinsic vascularisation for tissue engineering applications. PLOS ONE 11:e0149799. doi: 10.1371/journal.pone.0149799

Chan, S. J., Love, C., Spector, M., Cool, S. M., Nurcombe, V., and Lo, E. H. (2017) Endogenous regeneration: Engineering growth factors for stroke. Neurochem. Int. 107, 57-65. doi: 10.1016/j.neuint.2017.03.024

Chandler, L. A., Gu, D. L., Ma, C., Gonzalez, A. M., Doukas, J., Nguyen, T., et al. (2000). Matrix-enabled gene transfer for cutaneous wound repair. Wound Repair Regen. 8, 473-479. doi: 10.1046/j.1524-475x.2000.00473.x

Chandrakasan, G., Torchia, D. A., and Piez, K. A. (1976). Preparation of intact monomeric collagen from rat tail tendon and skin and the structure of the nonhelical ends in solution. J. Biol. Chem. 251, 6062-6067.

Charulatha, V., and Rajaram, A. (2003). Influence of different crosslinking treatments on the physical properties of collagen 
membranes. Biomaterials 24, 759-767. doi: 10.1016/S0142-9612(02) 00412-X

Chattopadhyay, S., and Raines, R. T. (2014). Review collagen-based biomaterials for wound healing. Biopolymers 101, 821-833. doi: 10.1002/bip.22486

Chen, F., Yoo, J. J., and Atala, A. (1999). Acellular collagen matrix as a possible "off the shelf" biomaterial for urethral repair. Urology 54, 407-410. doi: 10.1016/S0090-4295(99)00179-X

Chen, Z., Tang, M., Huang, D., Jiang, W., Li, M., Ji, H., et al. (2018). Real-time observation of leukocyte-endothelium interactions in tissue-engineered blood vessel. Lab Chip 18, 2047-2054. doi: 10.1039/C8LC00202A

Cherubino, M., Valdatta, L., Balzaretti, R., Pellegatta, I., Rossi, F., Protasoni, M., et al. (2016). Human adipose-derived stem cells promote vascularization of collagen-based scaffolds transplanted into nude mice. Regen. Med. 11, 261-271. doi: 10.2217/rme-2015-0010

Chervu, A., Moore, W. S., Chvapil, M., and Henderson, T. (1991). Efficacy and duration of antistaphylococcal activity comparing three antibiotics bonded to Dacron vascular grafts with a collagen release system. J. Vasc. Surg. 13, 897-901. doi: 10.1016/0741-5214(91)90057-2

Chiang, T. M., Postlethwaite, A. E., Beachey, E. H., Seyer, J. M., and Kang, A. H. (1978). Binding of chemotactic collagen-derived peptides to fibroblasts. The relationship to fibroblast chemotaxis. J. Clin. Invest. 62, 916-922. doi: 10.1172/JCI109219

Chiu, L. L., Radisic, M., and Vunjak-Novakovic, G. (2010). Bioactive scaffolds for engineering vascularized cardiac tissues. Macromol. Biosci. 10, 1286-1301. doi: 10.1002/mabi.201000202

Chlupac, J., Filova, E., and Bacakova, L. (2009). Blood vessel replacement: 50 years of development and tissue engineering paradigms in vascular surgery. Physiol. Res. 58, S119-S139.

Clowes, A. W. (1993). Intimal hyperplasia and graft failure. Cardiovasc. Pathol. 2, 179-186. doi: 10.1016/1054-8807(93)90058-A

Colunga, T., and Dalton, S. (2018). Building blood vessels with vascular progenitor cells. Trends Mol. Med. 24, 630-641. doi: 10.1016/j.molmed.2018.05.002

Cummings, C. L., Gawlitta, D., Nerem, R. M., and Stegemann, J. P. (2004). Properties of engineered vascular constructs made from collagen, fibrin, and collagen-fibrin mixtures. Biomaterials 25, 3699-3706. doi: 10.1016/j.biomaterials.2003.10.073

Davidenko, N., Schuster, C. F., Bax, D. V., Raynal, N., Farndale, R. W., Best, S. M., et al. (2015). Control of crosslinking for tailoring collagenbased scaffolds stability and mechanics. Acta Biomater. 25, 131-142. doi: 10.1016/j.actbio.2015.07.034

Delarive, T., Rossier, A., Rossier, S., Ravinet, E., Shaarawy, T., and Mermoud, A. (2003). Aqueous dynamic and histological findings after deep sclerectomy with collagen implant in an animal model. Br. J. Ophthalmol. 87, 1340-1344. doi: 10.1136/bjo.87.11.1340

Di Lullo, G. A., Sweeney, S. M., Korkko, J., Ala-Kokko, L., and San Antonio, J. D. (2002). Mapping the ligand-binding sites and disease-associated mutations on the most abundant protein in the human, type I collagen. J. Biol. Chem. 277, 4223-4231. doi: 10.1074/jbc.M110709200

Dogan, A., Elcin, A. E., and Elcin, Y. M. (2017). Translational applications of tissue engineering in cardiovascular medicine. Curr. Pharm. Des. 23, 903-914. doi: $10.2174 / 1381612823666161111141954$

Edelberg, J. M., Christie, P. D., and Rosenberg, R. D. (2001). Regulation of vascular bed-specific prothrombotic potential. Circ Res. 89, 117-124. doi: 10.1161/hh1401.093954

Ehrmann, R. L., and Gey, G. O. (1956). The growth of cells on a transparent gel of reconstituted rat-tail collagen. J. Natl. Cancer Inst. 16, 1375-1403.

Eshar, D., Wyre, N. R., and Schoster, J. V. (2011). Use of collagen shields for treatment of chronic bilateral corneal ulcers in a pet rabbit. J. Small Anim. Pract. 52, 380-383. doi: 10.1111/j.1748-5827.2011.01077.x

Exposito, J. Y., Cluzel, C., Garrone, R., and Lethias, C. (2002). Evolution of collagens. Anat. Rec. 268, 302-316. doi: 10.1002/ar.10162

Exposito, J. Y., Le Guellec, D., Lu, Q., and Garrone, R. (1991). Short chain collagens in sponges are encoded by a family of closely related genes. J. Biol. Chem. 266, 21923-21928.

Exposito, J. Y., Valcourt, U., Cluzel, C., and Lethias, C. (2010). The fibrillar collagen family. Int. J. Mol. Sci. 11, 407-426. doi: 10.3390/ijms11020407

Farndale, R. W., Sixma, J. J., Barnes, M. J., and de Groot, P. G. (2004). The role of collagen in thrombosis and hemostasis. J.
Thromb. Haemost. 2, 561-573. doi: 10.1111/j.1538-7836.2004. 00665.x

Fernandez, C. E., Yen, R. W., Perez, S. M., Bedell, H. W., Povsic, T. J., Reichert, W. M., et al. (2016). Human vascular microphysiological system for in vitro drug screening. Sci. Rep. 6:21579. doi: 10.1038/srep21579

Fleck, C. A., and Simman, R. (2010). Modern collagen wound dressings: function and purpose. J. Am. Col. Certif. Wound Spec. 2, 50-54. doi: 10.1016/j.jcws.2010.12.003

Fortunato, T. M., De Bank, P. A., and Pula, G. (2017). Vascular regenerative surgery: promised land for tissue engineers? Int. J. Stem Cell Res. Transplant. 5, 268-276. doi: 10.19070/2328-3548-1700041

Freischlag, J. A., and Moore, W. S. (1990). Clinical experience with a collagenimpregnated knitted Dacron vascular graft. Ann. Vasc. Surg. 4, 449-454. doi: 10.1016/S0890-5096(07)60069-7

Friess, W. (1998). Collagen-biomaterial for drug delivery. Eur. J. Pharm. Biopharm. 45, 113-136. doi: 10.1016/S0939-6411(98)00017-4

Furthmayr, H., and Timpl, R. (1976). Immunochemistry of collagens and procollagens. Int. Rev. Connect Tissue Res. 7, 61-99. doi: 10.1016/B978-0-12-363707-9.50008-3

Gallop, P. M., and Paz, M. A. (1975). Posttranslational protein modifications, with special attention to collagen and elastin. Physiol. Rev. 55, 418-487. doi: 10.1152/physrev.1975.55.3.418

Gao, J., Liu, J., Gao, Y., Wang, C., Zhao, Y., Chen, B., et al. (2011). A myocardial patch made of collagen membranes loaded with collagen-binding human vascular endothelial growth factor accelerates healing of the injured rabbit heart. Tissue Eng. Part A 17, 2739-2747. doi: 10.1089/ten.tea.2011.0105

Garoffolo, G., Madonna, R., de Caterina, R., and Pesce, M. (2018). Cell based mechanosensing in vascular patho-biology: more than a simple go-with the flow. Vascul. Pharmacol. 111, 7-14. doi: 10.1016/j.vph.2018.06.013

Gaudet, I. D., and Shreiber, D. I. (2012). Characterization of methacrylated type-I collagen as a dynamic, photoactive hydrogel. Biointerphases 7:25. doi: 10.1007/s13758-012-0025-y

Girton, T. S., Oegema, T. R., Grassl, E. D., Isenberg, B. C., and Tranquillo, R. T. (2000). Mechanisms of stiffening and strengthening in media-equivalents fabricated using glycation. J. Biomech. Eng. 122, 216-223. doi: 10.1115/1.429652

Gruber, H. E., Hoelscher, G. L., Leslie, K., Ingram, J. A., and Hanley, E. N., Jr. (2006). Three-dimensional culture of human disc cells within agarose or a collagen sponge: assessment of proteoglycan production. Biomaterials 27, 371-376. doi: 10.1016/j.biomaterials.2005.06.032

Gruber, H. E., Leslie, K., Ingram, J., Norton, H. J., and Hanley, E. N. (2004). Cellbased tissue engineering for the intervertebral disc: in vitro studies of human disc cell gene expression and matrix production within selected cell carriers. Spine J. 4, 44-55. doi: 10.1016/S1529-9430(03)00425-X

Guidoin, R., Marois, Y., Deng, X., Chakfe, N., Marois, M., Roy, R., et al. (1996). Can collagen impregnated polyester arterial prostheses be recommended as small diameter blood conduits? ASAIO J. 42, 974-983. doi: 10.1097/00002480-199642060-00010

Gullberg, D., Gehlsen, K. R., Turner, D. C., Ahlen, K., Zijenah, L. S., Barnes, M. J., et al. (1992). Analysis of alpha 1 beta 1, alpha 2 beta 1 and alpha 3 beta 1 integrins in cell-collagen interactions: identification of conformation dependent alpha 1 beta 1 binding sites in collagen type I. EMBO J. 11, 3865-3873. doi: 10.1002/j.1460-2075.1992.tb 05479.x

Habermehl, J., Skopinska, J., Boccafoschi, F., Sionkowska, A., Kaczmarek, H., Laroche, G., et al. (2005). Preparation of ready-to-use, stockable and reconstituted collagen. Macromol. Biosci. 5, 821-828. doi: 10.1002/mabi.200500102

Halka, A. T., Turner, N. J., Carter, A., Ghosh, J., Murphy, M. O., Kirton, J. P., et al. (2008). The effects of stretch on vascular smooth muscle cell phenotype in vitro. Cardiovasc. Pathol. 17, 98-102. doi: 10.1016/j.carpath.2007.03.001

Hao, W., Han, J., Chu, Y., Huang, L., Zhuang, Y., Sun, J., et al. (2018). Collagen/heparin bi-affinity multilayer modified collagen scaffolds for controlled bFGF release to improve angiogenesis in vivo. Macromol. Biosci. 18:e1800086. doi: 10.1002/mabi.201870028

He, Q., Zhao, Y., Chen, B., Xiao, Z., Zhang, J., Chen, L., et al. (2011). Improved cellularization and angiogenesis using collagen scaffolds chemically conjugated with vascular endothelial growth factor. Acta Biomater. 7, 1084-1093. doi: $10.1016 /$ j.actbio.2010.10.022 
He, W., Yong, T., Teo, W. E., Ma, Z., and Ramakrishna, S. (2005). Fabrication and endothelialization of collagen-blended biodegradable polymer nanofibers: potential vascular graft for blood vessel tissue engineering. Tissue Eng. 11, 1574-1588. doi: 10.1089/ten.2005.11.1574

Herten, M., Idelevich, E. A., Sielker, S., Becker, K., Scherzinger, A. S., Osada, N., et al. (2017). Vascular graft impregnation with antibiotics: the influence of high concentrations of rifampin, vancomycin, daptomycin, and bacteriophage endolysin HY-133 on viability of vascular cells. Med. Sci. Monit. Basic Res. 23, 250-257. doi: 10.12659/MSMBR.902879

Hirai, J., Kanda, K., Oka, T., and Matsuda, T. (1994). Highly oriented, tubular hybrid vascular tissue for a low pressure circulatory system. ASAIO J. 40, M383-M388. doi: 10.1097/00002480-199407000-00027

Holmes, R., Yang, X. B., Dunne, A., Florea, L., Wood, D., and Tronci, G. (2017). Thiol-ene photo-click collagen-PEG hydrogels: impact of water-soluble photoinitiators on cell viability, gelation kinetics and rheological properties. Polymers 9:226. doi: 10.3390/polym9060226

Houtchens, G. R., Foster, M. D., Desai, T. A., Morgan, E. F., and Wong, J. Y. (2008). Combined effects of microtopography and cyclic strain on vascular smooth muscle cell orientation. J. Biomech. 41, 762-769. doi: 10.1016/j.jbiomech.2007.11.027

Hulmes, D. J. (2002). Building collagen molecules, fibrils, and suprafibrillar structures. J. Struct. Biol. 137, 2-10. doi: 10.1006/jsbi.2002.4450

Humphries, A. W., Hawk, W. A., and Cuthbertson, A. M. (1961). Arterial prosthesis of collagen-impregnated Dacron tulle. Surgery 50, 947-954.

Huzella, T., and Lengyel, J. (1932). Orientation de la croissance des cultures de tissus sur la trame fibrillaire artificielle coagulée de la solution de "collagène A" (Nageotte) par les forces de la cristallisation. Compt. Rend. Soc. Biol. 109, 515-518.

Ishikawa, Y., and Bachinger, H. P. (2013). A molecular ensemble in the rER for procollagen maturation. Biochim. Biophys. Acta 1833, 2479-2491. doi: 10.1016/j.bbamcr.2013.04.008

Ivester, K. M., Adams, S. B., Moore, G. E., Van Sickle, D. C., and Lescun, T. B. (2006). Gentamicin concentrations in synovial fluid obtained from the tarsocrural joints of horses after implantation of gentamicin-impregnated collagen sponges. Am. J. Vet. Res. 67, 1519-1526. doi: 10.2460/ajvr.67.9.1519

Jenkins, E., Moss, J. B., Pace, J. M., and Bridgewater, L. C. (2005). The new collagen gene COL27A1 contains SOX9-responsive enhancer elements. Matrix Biol. 24, 177-184. doi: 10.1016/j.matbio.2005.02.004

Jeong, S. I., Kim, S. Y., Cho, S. K., Chong, M. S., Kim, K. S., Kim, H., et al. (2007). Tissue-engineered vascular grafts composed of marine collagen and PLGA fibers using pulsatile perfusion bioreactors. Biomaterials 28, 1115-1122. doi: 10.1016/j.biomaterials.2006.10.025

Johnson, K. A., Rogers, G. J., Roe, S. C., Howlett, C. R., Clayton, M. K., Milthorpe, B. K., et al. (1999). Nitrous acid pretreatment of tendon xenografts cross-linked with glutaraldehyde and sterilized with gamma irradiation. Biomaterials 20, 1003-1015. doi: 10.1016/S0142-9612(98)90187-9

Jonas, R. A., Schoen, F. J., Ziemer, G., Britton, L., and Castaneda, A. R. (1987). Biological sealants and knitted Dacron conduits: comparison of collagen and fibrin glue pretreatments in circulatory models. Ann. Thorac. Surg. 44, 283-290. doi: 10.1016/S0003-4975(10)62075-9

Kanematsu, A., Yamamoto, S., Ozeki, M., Noguchi, T., Kanatani, I., Ogawa, O., et al. (2004). Collagenous matrices as release carriers of exogenous growth factors. Biomaterials 25, 4513-4520. doi: 10.1016/j.biomaterials.2003.11.035

Kannan, R. Y., Salacinski, H. J., Butler, P. E., Hamilton, G., and Seifalian, A. M. (2005). Current status of prosthetic bypass grafts: a review. J. Biomed. Mater. Res. B Appl. Biomater. 74, 570-581. doi: 10.1002/jbm.b.30247

Kato, N., Yamagishi, M., Kanda, K., Miyazaki, T., Maeda, Y., Yamanami, M., et al. (2016). First successful clinical application of the in vivo tissueengineered autologous vascular graft. Ann. Thorac. Surg. 102, 1387-1390. doi: 10.1016/j.athoracsur.2016.06.095

Kaufman, H. E., Steinemann, T. L., Lehman, E., Thompson, H. W., Varnell, E. D., Jacob-LaBarre, J. T., et al. (1994). Collagen-based drug delivery and artificial tears. J. Ocul. Pharmacol. 10, 17-27. doi: 10.1089/jop.19 94.10.17

Keuren, J. F., Wielders, S. J., Driessen, A., Verhoeven, M., Hendriks, M., and Lindhout, T. (2004). Covalently-bound heparin makes collagen thromboresistant. Arterioscler. Thromb. Vasc. Biol. 24, 613-617. doi: 10.1161/01.ATV.0000116026.18945.66
Kobayashi, J., Backer, C. L., Zales, V. R., Crawford, S. E., Muster, A. J., and Mavroudis, C. (1993). Failure of the Hemashield extension in right ventricle-to-pulmonary artery conduits. Ann. Thorac. Surg. 56, 277-281. doi: 10.1016/0003-4975(93)91159-K

Koch, S., Yao, C., Grieb, G., Prevel, P., Noah, E. M., and Steffens, G. C. (2006). Enhancing angiogenesis in collagen matrices by covalent incorporation of VEGF. J. Mater. Sci. Mater. Med. 17, 735-741. doi: 10.1007/s10856-006-9684-x

Koens, M. J., Faraj, K. A., Wismans, R. G., van der Vliet, J. A., Krasznai, A. G., Cuijpers, V. M., et al. (2010). Controlled fabrication of triple layered and molecularly defined collagen/elastin vascular grafts resembling the native blood vessel. Acta Biomater. 6, 4666-4674. doi: 10.1016/j.actbio.2010.06.038

Koens, M. J., Krasznai, A. G., Hanssen, A. E., Hendriks, T., Praster, R., Daamen, W. F., et al. (2015). Vascular replacement using a layered elastin-collagen vascular graft in a porcine model: one week patency versus one month occlusion. Organogenesis 11, 105-121. doi: 10.1080/15476278.2015.1038448

Kon, E., Delcogliano, M., Filardo, G., Busacca, M., Di Martino, A., and Marcacci, M. (2011). Novel nano-composite multilayered biomaterial for osteochondral regeneration: a pilot clinical trial. Am. J. Sports Med. 39, 1180-1190. doi: $10.1177 / 0363546510392711$

Konitsiotis, A. D., Raynal, N., Bihan, D., Hohenester, E., Farndale, R. W., and Leitinger, B. (2008). Characterization of high affinity binding motifs for the discoidin domain receptor DDR2 in collagen. J. Biol. Chem. 283, 6861-6868. doi: 10.1074/jbc.M709290200

Laflamme, K., Roberge, C. J., Labonte, J., Pouliot, S., D’Orleans-Juste, P., Auger, F. A., et al. (2005). Tissue-engineered human vascular media with a functional endothelin system. Circulation 111, 459-464. doi: 10.1161/01.CIR.0000153850.53419.50

Laiva, A. L., Raftery, R. M., Keogh, M. B., and O'Brien, F. J. (2018). Pro-angiogenic impact of SDF-1alpha gene-activated collagen-based scaffolds in stem cell driven angiogenesis. Int. J. Pharm. 544, 372-379. doi: 10.1016/j.ijpharm.2018.03.032

Lee, A. R. (2005). Enhancing dermal matrix regeneration and biomechanical properties of 2nd degree-burn wounds by EGF-impregnated collagen sponge dressing. Arch. Pharm. Res. 28, 1311-1316. doi: 10.1007/BF02978217

Lee, C. H., Singla, A., and Lee, Y. (2001). Biomedical applications of collagen. Int. J. Pharm. 221, 1-22. doi: 10.1016/S0378-5173(01)00691-3

Lesman, A., Rosenfeld, D., Landau, S., and Levenberg, S. (2016). Mechanical regulation of vascular network formation in engineered matrices. Adv. Drug Deliv. Rev. 96, 176-182. doi: 10.1016/j.addr.2015.07.005

L'Heureux, N., Dusserre, N., Konig, G., Victor, B., Keire, P., Wight, T. N., et al. (2006). Human tissue-engineered blood vessels for adult arterial revascularization. Nat. Med. 12, 361-365. doi: 10.1038/nm1364

L'Heureux, N., Germain, L., Labbe, R., and Auger, F. A. (1993). In vitro construction of a human blood vessel from cultured vascular cells: a morphologic study. J. Vasc. Surg. 17, 499-509. doi: 10.1016/0741-5214(93)90150-K

Li, C., and Xu, Q. (2007). Mechanical stress-initiated signal transduction in vascular smooth muscle cells in vitro and in vivo. Cell Signal 19, 881-891. doi: 10.1016/j.cellsig.2007.01.004

Li, X., Xu, J., Nicolescu, C. T., Marinelli, J. T., and Tien, J. (2017). Generation, endothelialization, and microsurgical suture anastomosis of strong 1-mm-diameter collagen tubes. Tissue Eng. Part A 23, 335-344. doi: 10.1089/ten.tea.2016.0339

Liu, X., Zheng, C., Luo, X., Wang, X., and Jiang, H. (2019). Recent advances of collagen-based biomaterials: multi-hierarchical structure, modification and biomedical applications. Mater. Sci. Eng. C. Mater. Biol. Appl. 99, 1509-1522. doi: 10.1016/j.msec.2019.02.070

Liu, Y., Gan, L., Carlsson, D. J., Fagerholm, P., Lagali, N., Watsky, M. A., et al. (2006). A simple, cross-linked collagen tissue substitute for corneal implantation. Invest. Ophthalmol. Vis. Sci. 47, 1869-1875. doi: $10.1167 /$ iovs.05-1339

Long, J. L., and Tranquillo, R. T. (2003). Elastic fiber production in cardiovascular tissue-equivalents. Matrix Biol. 22, 339-350. doi: 10.1016/S0945-053X(03)00052-0

Loy, C., Meghezi, S., Levesque, L., Pezzoli, D., Kumra, H., Reinhardt, D., et al. (2016). A planar model of the vessel wall from cellularized-collagen scaffolds: focus on cell-matrix interactions in mono-, bi- and tri-culture models. Biomater. Sci. 5, 153-162. doi: 10.1039/C6BM00643D 
Loy, C., Pezzoli, D., Candiani, G., and Mantovani, D. (2018). A cost-effective culture system for the in vitro assembly, maturation, and stimulation of advanced multilayered multiculture tubular tissue models. Biotechnol. J. 13. doi: 10.1002/biot.201700359

Lucas, P. A., Syftestad, G. T., Goldberg, V. M., and Caplan, A. I. (1989). Ectopic induction of cartilage and bone by water-soluble proteins from bovine bone using a collagenous delivery vehicle. J. Biomed. Mater. Res. 23, 23-39. doi: $10.1002 / \mathrm{jbm} .820231306$

Lynn, A. K., Yannas, I. V., and Bonfield, W. (2004). Antigenicity and immunogenicity of collagen. J. Biomed. Mater. Res. B Appl. Biomater. 71, 343-354. doi: 10.1002/jbm.b.30096

Matassi, F., Nistri, L., Chicon Paez, D., and Innocenti, M. (2011). New biomaterials for bone regeneration. Clin. Cases Miner. Bone Metab. 8, 21-24.

Matsuda, T., Kitamura, T., Iwata, H., Takano, H., and Akutsu, T. (1988). A hybrid artificial vascular graft based upon an organ reconstruction model. Significance and design criteria of an artificial basement membrane. ASAIO Trans. 34, 640-643.

Meghezi, S., Couet, F., Chevallier, P., and Mantovani, D. (2012). Effects of a pseudophysiological environment on the elastic and viscoelastic properties of collagen gels. Int. J. Biomater. 2012:319290. doi: 10.1155/2012/319290

Meghezi, S., Seifu, D. G., Bono, N., Unsworth, L., Mequanint, K., and Mantovani, D. (2015). Engineering 3D cellularized collagen gels for vascular tissue regeneration. J. Vis. Exp. e52812. doi: 10.3791/52812

Meyer, M. (2019). Processing of collagen based biomaterials and the resulting materials properties. Biomed. Eng. Online 18:24. doi: 10.1186/ s12938-019-0647-0

Nemeno-Guanzoni, J. G., Lee, S., Berg, J. R., Jo, Y. H., Yeo, J. E., Nam, B. M., et al. (2012). Trends in tissue engineering for blood vessels. J. Biomed. Biotechnol. 2012:956345. doi: 10.1155/2012/956345

Nicosia, R. F., Belser, P., Bonanno, E., and Diven, J. (1991). Regulation of angiogenesis in vitro by collagen metabolism. In Vitro Cell Dev. Biol. 27A, 961-966. doi: 10.1007/BF02631124

Niklason, L. E., Gao, J., Abbott, W. M., Hirschi, K. K., Houser, S., Marini, R., et al. (1999). Functional arteries grown in vitro. Science 284, 489-493. doi: 10.1126/science.284.5413.489

Noishiki, Y., Marat, D., Yamane, Y., Satoh, S., Ma, X. H., Iwai, Y., et al. (1996). A collagen coated fabric vascular prosthesis as a punctureable $\mathrm{A}-\mathrm{V}$ shunt. ASAIO J. 42, M687-M693. doi: 10.1097/00002480-199609000-00075

Pashneh-Tala, S., MacNeil, S., and Claeyssens, F. (2016). The tissue-engineered vascular graft-past, present, and future. Tissue Eng. Part B Rev. 22, 68-100. doi: 10.1089/ten.teb.2015.0100

Patino, M. G., Neiders, M. E., Andreana, S., Noble, B., and Cohen, R. E. (2002). Collagen as an implantable material in medicine and dentistry. J. Oral Implantol. 28, 220-225. doi: 10.1563/1548-1336(2002) $028<0220$ :CAAIMI>2.3.CO;2

Pawelec, K. M., Best, S. M., and Cameron, R. E. (2016). Collagen: a network for regenerative medicine. J. Mater. Chem. B 4, 6484-6496. doi: 10.1039/C6TB00807K

Pezzoli, D., Di Paolo, J., Kumra, H., Fois, G., Candiani, G., Reinhardt, D. P., et al. (2018). Fibronectin promotes elastin deposition, elasticity and mechanical strength in cellularised collagen-based scaffolds. Biomaterials 180, 130-142. doi: 10.1016/j.biomaterials.2018.07.013

Postlethwaite, A. E., Seyer, J. M., and Kang, A. H. (1978). Chemotactic attraction of human fibroblasts to type I, II, and III collagens and collagen-derived peptides. Proc. Natl. Acad. Sci U.S.A. 75, 871-875. doi: 10.1073/pnas.75.2.871

Potorac, S., Popa, M., Picton, L., Dulong, V., Verestiuc, L., and Le Cerf, D. (2014). Collagen functionalized with unsaturated cyclic anhydrides-interactions in solution and solid state. Biopolymers. 101, 228-236. doi: 10.1002/bip.22319

Prager, M. R., Hoblaj, T., Nanobashvili, J., Sporn, E., Polterauer, P., Wagner, O., et al. (2003). Collagen-versus gelatine-coated Dacron versus stretch PTFE bifurcation grafts for aortoiliac occlusive disease: long-term results of a prospective, randomized multicenter trial. Surgery 134, 80-85. doi: $10.1067 / \mathrm{msy} .2003 .179$

Pupkaite, J., Ahumada, M., McLaughlin, S., Temkit, M., Alaziz, S., Seymour, R., et al. (2017). Collagen-based photoactive agent for tissue bonding. ACS Appl. Mater. Interfaces 9, 9265-9270. doi: 10.1021/acsami.7b01984

Qiu, J., Zheng, Y., Hu, J., Liao, D., Gregersen, H., Deng, X., et al. (2014). Biomechanical regulation of vascular smooth muscle cell functions: from in vitro to in vivo understanding. J. R. Soc. Interface 11:20130852. doi: 10.1098/rsif.2013.0852

Ravichandran, R., Islam, M. M., Alarcon, E. I., Samanta, A., Wang, S., Lundström, P., et al. (2016). Functionalised type-I collagen as a hydrogel building block for bio-orthogonal tissue engineering applications. J. Mat. Chem. B 4, 318-326. doi: 10.1039/C5TB02035B

Reigel, M. M., Hollier, L. H., Pairolero, P. C., and Hallett, J. W. Jr. (1988). Early experience with a new collagen-impregnated aortic graft. Am. Surg. 54, 134-136.

Robert, J., Weber, B., Frese, L., Emmert, M. Y., Schmidt, D., von Eckardstein, A., et al. (2013). A three-dimensional engineered artery model for in vitro atherosclerosis research. PLoS ONE 8:e79821. doi: 10.1371/journal.pone.0079821

Rodrigues, C. V., Serricella, P., Linhares, A. B., Guerdes, R. M., Borojevic, R., Rossi, M. A., et al. (2003). Characterization of a bovine collagen-hydroxyapatite composite scaffold for bone tissue engineering. Biomaterials 24, 4987-4997. doi: 10.1016/S0142-9612(03)00410-1

Roll, S., Muller-Nordhorn, J., Keil, T., Scholz, H., Eidt, D., Greiner, W., et al. (2008). Dacron vs. PTFE as bypass materials in peripheral vascular surgery-systematic review and meta-analysis. BMC Surg. 8:22. doi: 10.1186/1471-2482-8-22

Ronaldson-Bouchard, K., and Vunjak-Novakovic, G. (2018). Organs-on-a-chip: a fast track for engineered human tissues in drug development. Cell Stem Cell 22, 310-324. doi: 10.1016/j.stem.2018.02.011

Rýglová, Š., Braun, M., and Suchý, T. (2017). Collagen and its modificationscrucial aspects with concern to its processing and analysis. Macromol. Mater. Eng. 302:1600460. doi: 10.1002/mame.201600460

Salamanca, E., Hsu, C. C., Huang, H. M., Teng, N. C., Lin, C. T., Pan, Y. H., et al. (2018). Bone regeneration using a porcine bone substitute collagen composite in vitro and in vivo. Sci. Rep. 8:984. doi: 10.1038/s41598-018-19629-y

Sarkar, S., Sales, K. M., Hamilton, G., and Seifalian, A. M. (2007). Addressing thrombogenicity in vascular graft construction. J. Biomed. Mater. Res. B Appl. Biomater. 82, 100-108. doi: 10.1002/jbm.b.30710

Scharn, D. M., Oyen, W. J., Klemm, P. L., Verhofstad, A. A., and van der Vliet, J. A. (2006). Thrombogenicity and related biological properties of heparin bonded collagen coated polyester and human umbilical vein prosthetic vascular grafts. J. Surg. Res. 134, 182-189. doi: 10.1016/j.jss.2006.01.025

Schmidt, V. J., Wietbrock, J. O., Leibig, N., Gloe, T., Henn, D., Hernekamp, J. F., et al. (2017). Collagen-elastin and collagen-glycosaminoglycan scaffolds promote distinct patterns of matrix maturation and axial vascularization in arteriovenous loop-based soft tissue flaps. Ann. Plast. Surg. 79, 92-100. doi: 10.1097/SAP.0000000000001096

Schmitt, F. O., Levine, L., Drake, M. P., Rubin, A. L., Pfahl, D., and Davison, P. F. (1964). The antigenicity of tropocollagen. Proc. Natl. Acad. Sci. U.S.A. 51, 493-497. doi: 10.1073/pnas.51.3.493

Schneider, F., O'Connor, S., and Becquemin, J. P. (2008). Efficacy of collagen silvercoated polyester and rifampin-soaked vascular grafts to resist infection from MRSA and Escherichia coli in a dog model. Ann. Vasc. Surg. 22, 815-821. doi: 10.1016/j.avsg.2008.06.011

Schoneberg, J., De Lorenzi, F., Theek, B., Blaeser, A., Rommel, D., Kuehne, A. J. C., et al. (2018). Engineering biofunctional in vitro vessel models using a multilayer bioprinting technique. Sci. Rep. 8:10430. doi: 10.1038/s41598-018-28715-0

Schroeder, J. W. Jr., Rastatter, J. C., and Walner, D. L. (2007). Effect of vascular endothelial growth factor on laryngeal wound healing in rabbits. Otolaryngol. Head Neck Surg. 137, 465-470. doi: 10.1016/j.otohns.2007.04.027

Schutte, S. C., Chen, Z., Brockbank, K. G., and Nerem, R. M. (2010a). Cyclic strain improves strength and function of a collagen-based tissue-engineered vascular media. Tissue Eng. Part A 16, 3149-3157. doi: 10.1089/ten.tea.2010.0009

Schutte, S. C., Chen, Z., Brockbank, K. G., and Nerem, R. M. (2010b). Tissue engineering of a collagen-based vascular media: Demonstration of functionality. Organogenesis 6, 204-211. doi: 10.4161/org.6.4.12651

Schweitzer, M. H., Suo, Z., Avci, R., Asara, J. M., Allen, M. A., Arce, F. T., et al. (2007). Analyses of soft tissue from Tyrannosaurus rex suggest the presence of protein. Science 316, 277-280. doi: 10.1126/science.1138709

Scott, S. M., Gaddy, L. R., Sahmel, R., and Hoffman, H. (1987). A collagen coated vascular prosthesis. J. Cardiovasc. Surg. 28, 498-504.

Seifu, D. G., Purnama, A., Mequanint, K., and Mantovani, D. (2013). Smalldiameter vascular tissue engineering. Nat. Rev. Cardiol. 10, 410-421. doi: $10.1038 /$ nrcardio. 2013.77 
Seliktar, D., Black, R. A., Vito, R. P., and Nerem, R. M. (2000). Dynamic mechanical conditioning of collagen-gel blood vessel constructs induces remodeling in vitro. Ann. Biomed. Eng. 28, 351-362. doi: 10.1114/1.275

Shen, Y. H., Shoichet, M. S., and Radisic, M. (2008). Vascular endothelial growth factor immobilized in collagen scaffold promotes penetration and proliferation of endothelial cells. Acta Biomater. 4, 477-489. doi: 10.1016/j.actbio.2007.12.011

Shih, Y. R., Chen, C. N., Tsai, S. W., Wang, Y. J., and Lee, O. K. (2006). Growth of mesenchymal stem cells on electrospun type I collagen nanofibers. Stem Cells 24, 2391-2397. doi: 10.1634/stemcells.2006-0253

Shoulders, M. D., and Raines, R. T. (2009). Collagen structure and stability. Annu. Rev. Biochem. 78, 929-958. doi: 10.1146/annurev.biochem.77.032207.120833

Smethurst, P. A., Onley, D. J., Jarvis, G. E., O’Connor, M. N., Knight, C. G., Herr, A. B., et al. (2007). Structural basis for the platelet-collagen interaction: the smallest motif within collagen that recognizes and activates platelet glycoprotein VI contains two glycine-proline-hydroxyproline triplets. J. Biol. Chem. 282, 1296-1304. doi: 10.1074/jbc.M606479200

Sripriya, R., Kumar, M. S., and Sehgal, P. K. (2004). Improved collagen bilayer dressing for the controlled release of drugs. J. Biomed. Mater. Res. B Appl. Biomater. 70, 389-396. doi: 10.1002/jbm.b.30051

Stanley, A. G., Patel, H., Knight, A. L., and Williams, B. (2000). Mechanical straininduced human vascular matrix synthesis: the role of angiotensin II. J. Renin. Angiotensin Aldosterone Syst. 1, 32-35. doi: 10.3317/jraas.2000.007

Steffens, G. C., Yao, C., Prevel, P., Markowicz, M., Schenck, P., Noah, E. M., et al. (2004). Modulation of angiogenic potential of collagen matrices by covalent incorporation of heparin and loading with vascular endothelial growth factor. Tissue Eng. 10, 1502-1509. doi: 10.1089/ten.2004.10.1502

Stephan, E. B., Renjen, R., Lynch, S. E., and Dziak, R. (2000). Plateletderived growth factor enhancement of a mineral-collagen bone substitute. $J$. Periodontol. 71, 1887-1892. doi: 10.1902/jop.2000.71.12.1887

Stitzel, J., Liu, J., Lee, S. J., Komura, M., Berry, J., Soker, S., et al. (2006). Controlled fabrication of a biological vascular substitute. Biomaterials 27, 1088-1094. doi: 10.1016/j.biomaterials.2005.07.048

Suehiro, K., Hata, T., Yoshitaka, H., Tsushima, Y., Matsumoto, M., Ohtani, S., et al. (2003). Impact of collagen-coated and gelatine-impregnated woven Dacron branched grafts on the early postoperative period. Jpn. J. Thorac. Cardiovasc. Surg. 51, 641-645. doi: 10.1007/s11748-003-0001-z

Sugiura, H., Yunoki, S., Kondo, E., Ikoma, T., Tanaka, J., and Yasuda, K. (2009). In vivo biological responses and bioresorption of tilapia scale collagen as a potential biomaterial. J. Biomater. Sci. Polym. Ed. 20, 1353-1368. doi: 10.1163/092050609X12457418396658

Swartz, D. D., and Andreadis, S. T. (2013). Animal models for vascular tissue-engineering. Curr. Opin. Biotechnol. 24, 916-925. doi: 10.1016/j.copbio.2013.05.005

Toda, N., Nakanishi, S., and Tanabe, S. (2013). Aldosterone affects blood flow and vascular tone regulated by endothelium-derived NO: therapeutic implications. Br. J. Pharmacol. 168, 519-533. doi: 10.1111/j.1476-5381.2012.02194.x

Tranquillo, R. T., Girton, T. S., Bromberek, B. A., Triebes, T. G., and Mooradian, D. L. (1996). Magnetically orientated tissue-equivalent tubes: application to a circumferentially orientated media-equivalent. Biomaterials 17, 349-357. doi: 10.1016/0142-9612(96)85573-6

Tresoldi, C., Bianchi, E., Pellegata, A. F., Dubini, G., and Mantero, S. (2017). Estimation of the physiological mechanical conditioning in vascular tissue engineering by a predictive fluid-structure interaction approach. Comput. Methods Biomech. Biomed. Eng. 20, 1077-1088. doi: 10.1080/10255842.2017.1332192

Tronci, G., Russell, S. J., and Wood, D. J. (2013). Photo-active collagen systems with controlled triple helix architecture. J. Mater. Chem. B 1, 3705-3715. doi: $10.1039 /$ c3tb20720j

Truskey, G. A., and Fernandez, C. E. (2015). Tissue-engineered blood vessels as promising tools for testing drug toxicity. Expert Opin. Drug Metab. Toxicol. 11, 1021-1024. doi: 10.1517/17425255.2015.1047342

Vernon, R. B., Lara, S. L., Drake, C. J., Iruela-Arispe, M. L., Angello, J. C., Little, C. D., et al. (1995). Organized type I collagen influences endothelial patterns during "spontaneous angiogenesis in vitro": planar cultures as models of vascular development. In Vitro Cell Dev. Biol. Anim. 31, 120-131. doi: 10.1007/BF02633972
Voorhees, A. B. Jr., Jaretzki, A., and Blakemore, A. H. (1952). The use of tubes constructed from vinyon "N" cloth in bridging arterial defects. Ann. Surg. 135, 332-336. doi: 10.1097/00000658-195203000-00006

Wahl, E. A., Schenck, T. L., Machens, H. G., and Balmayor, E. R. (2016). VEGF released by deferoxamine preconditioned mesenchymal stem cells seeded on collagen-GAG substrates enhances neovascularization. Sci. Rep. 6:36879. doi: $10.1038 /$ srep36879

Wallace, D. G., and Rosenblatt, J. (2003). Collagen gel systems for sustained delivery and tissue engineering. Adv. Drug Deliv. Rev. 55, 1631-1649. doi: 10.1016/j.addr.2003.08.004

Weinberg, C. B., and Bell, E. (1986). A blood vessel model constructed from collagen and cultured vascular cells. Science 231, 397-400. doi: $10.1126 /$ science. 2934816

Willoughby, C. E., Batterbury, M., and Kaye, S. B. (2002). Collagen corneal shields. Surv. Ophthalmol. 47, 174-182. doi: 10.1016/S0039-6257(01) 00304-6

Wissing, T. B., Bonito, V., Bouten, C. V. C., and Smits, A. (2017). Biomaterialdriven in situ cardiovascular tissue engineering-a multi-disciplinary perspective. NPJ Regen. Med. 2:18. doi: 10.1038/s41536-017-0023-2

Wissink, M. J., Beernink, R., Poot, A. A., Engbers, G. H., Beugeling, T., van Aken, W. G., et al. (2000). Improved endothelialization of vascular grafts by local release of growth factor from heparinized collagen matrices. J. Control Release 64, 103-114. doi: 10.1016/S0168-3659(99)00145-5

Wolf, F., Vogt, F., Schmitz-Rode, T., Jockenhoevel, S., and Mela, P. (2016). Bioengineered vascular constructs as living models for in vitro cardiovascular research. Drug Discov. Today 21, 1446-1455. doi: 10.1016/j.drudis.2016.04.017

Wood, A., Ogawa, M., Portier, R. J., Schexnayder, M., Shirley, M., and Losso, J. N. (2008). Biochemical properties of alligator (Alligator mississippiensis) bone collagen. Comp. Biochem. Physiol. B Biochem. Mol. Biol. 151, 246-249. doi: 10.1016/j.cbpb.2008.05.015

Xiang, Z., Liao, R., Kelly, M. S., and Spector, M. (2006). CollagenGAG scaffolds grafted onto myocardial infarcts in a rat model: a delivery vehicle for mesenchymal stem cells. Tissue Eng. 12, 2467-2478. doi: $10.1089 /$ ten.2006.12.2467

Yannas, I. V., Burke, J. F., Orgill, D. P., and Skrabut, E. M. (1982). Wound tissue can utilize a polymeric template to synthesize a functional extension of skin. Science 215, 174-176. doi: 10.1126/science.7031899

Yates, S. G., Barros D'Sa, A. A., Berger, K., Fernandez, L. G., Wood, S. J., Rittenhouse, E. A., et al. (1978). The preclotting of porous arterial prostheses. Ann. Surg. 188, 611-622. doi: 10.1097/00000658-197811000-00005

Yeager, R. A., Taylor, L. M., Jr., Moneta, G. L., Edwards, J. M., Nicoloff, A. D., et al. (1999). Improved results with conventional management of infrarenal aortic infection. J. Vasc. Surg. 30, 76-83. doi: 10.1016/S0741-5214(99)70178-3

Yu, H., Cao, B., Feng, M., Zhou, Q., Sun, X., Wu, S., et al. (2010). Combinated transplantation of neural stem cells and collagen type I promote functional recovery after cerebral ischemia in rats. Anat. Rec. (Hoboken) 293, 911-917. doi: 10.1002/ar.20941

Zhang, D., Wu, X., Chen, J., and Lin, K. (2018). The development of collagen based composite scaffolds for bone regeneration. Bioact. Mater. 3, 129-138. doi: 10.1016/j.bioactmat.2017.08.004

Zhang, W. J., Liu, W., Cui, L., and Cao, Y. (2007). Tissue engineering of blood vessel. J. Cell. Mol. Med. 11, 945-957. doi: 10.1111/j.1582-4934.2007.00099.x

Ziegler, T., Alexander, R. W., and Nerem, R. M. (1995). An endothelial cell-smooth muscle cell co-culture model for use in the investigation of flow effects on vascular biology. Ann. Biomed. Eng. 23, 216-225. doi: 10.1007/BF02584424

Conflict of Interest Statement: The authors declare that the research was conducted in the absence of any commercial or financial relationships that could be construed as a potential conflict of interest.

Copyright $\odot 2019$ Copes, Pien, Van Vlierberghe, Boccafoschi and Mantovani. This is an open-access article distributed under the terms of the Creative Commons Attribution License (CC BY). The use, distribution or reproduction in other forums is permitted, provided the original author(s) and the copyright owner(s) are credited and that the original publication in this journal is cited, in accordance with accepted academic practice. No use, distribution or reproduction is permitted which does not comply with these terms. 